Canadian

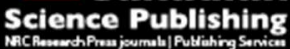

Environmental Reviews Dossiers environnement

\title{
A Global Review of the Spatial, Taxonomic, and Temporal Scope of Freshwater Fisheries Hydroacoustics Research
}

\begin{tabular}{|r|l|}
\hline Journal: & Environmental Reviews \\
\hline Manuscript ID & er-2016-0017.R1 \\
\hline Danuscript Type: & Review \\
\hline Complete List of Authors: & $\begin{array}{l}\text { Pollom, Riley; Memorial University of Newfoundland, Centre for Fisheries } \\
\text { Ecosystems Research; University of British Columbia, Institute for the } \\
\text { Oceans and Fisheries - Project Seahorse } \\
\text { Rose, George; Memorial University of Newfoundland Fisheries and Marine } \\
\text { Institute, Centre for Fisheries Ecosystems Research }\end{array}$ \\
\hline Keyword: & $\begin{array}{l}\text { freshwater hydroacoustics, target strength, body size, species ID, inland } \\
\text { fisheries }\end{array}$ \\
\hline &
\end{tabular}




\section{A Global Review of the Spatial, 2 Taxonomic, and Temporal Scope of 3 Freshwater Fisheries Hydroacoustics ${ }_{4}$ Research}

5 Riley A. Pollom ${ }^{1 * \Psi}$ and George A. Rose ${ }^{1 \#}$

$6 \quad{ }^{1}$ Centre for Fisheries Ecosystems Research, Fisheries and Marine

7 Institute of Memorial University of Newfoundland, St. John's,

8 Newfoundland and Labrador, Canada

$9{ }^{*}$ Current address: Project Seahorse, Institute for the Oceans and Fisheries, The University 10 of British Columbia, Vancouver, British Columbia, Canada

$11{ }^{\#}$ Current address: 4843 Cutlass Crt., Pender Island, British Columbia, Canada V0N 2M2

$12 \Psi$ Corresponding author: r.pollom@oceans.ubc.ca 


\section{Abstract}

25 This review assessed the status and scope of freshwater hydroacoustic fisheries research in

26 global aquatic ecosystems with emphasis on i) geographical and spatial scope, ii)

27 taxonomic range at the species and family levels (restricted to bony fishes of the

28 Actinopterygii and Sarcopterygii), and iii) temporal scope. Hydroacoustic measures have

29 been used by ecologists and managers of freshwater systems for several decades, with

30 major progress in technology and methods in recent years. A literature review indicated 296

31 research contributions that employed hydroacoustics to study freshwater fisheries in 294

32 different aquatic ecosystems. Spatially, hydroacoustics research in freshwater systems have

33 thus far been concentrated in developed countries, particularly in North America and

34 Northern and Central Europe ( $83 \%$ of the studies reviewed here). Most studies were small

35 in spatial scale and short-term, with $80 \%$ including only a single body of water and $63 \%$

36 conducted over a single year or season ( $75 \%$ spanning less than two years). In addition,

37 effects of fish morphology and behavior on acoustic target strength (TS) and taxonomic

38 identification are not well parameterized, with only 21 species receiving empirical study of

39 TS. Despite progress, the present study reveals gaps in the knowledge needed for wider

40 applications to management. These include larger biogeographical and temporal scales of

41 study and further empirical research on TS and taxonomic identification. Recent advances

42 in size rather than species-based methods and theory offer potential solutions to this issue

43 but require further investigation. We conclude with recommendations for systematic

44 hydroacoustic research to enable more effective monitoring, management, and conservation

45 of fisheries and freshwater ecosystems. 
46 Key Words: freshwater hydroacoustics, target strength, TS, body size, species ID, fisheries

47 surveys, inland fisheries.

48

49

50

51

52

53

54

55

56

57

58

59

60 


\section{Introduction}

62 Fisheries and plankton hydroacoustics utilizes scientific echosounders to interpret

63 density differences in water columns, in particular those caused by living organisms.

64 Scientific echosounders utilize calibrated sound waves travelling at approximately 1500

$65 \mathrm{~m} . \mathrm{s}^{-1}$ with known power, transmission and reception characteristics to measure the power

66 and "backscatter" of returned echoes. Most scientific echosounders use a narrow range of

67 frequencies centred on 38,120 , and $200 \mathrm{kHz}$, although other frequencies are sometimes

68 used and broadband echosounders using a wider range of frequencies are gaining increasing

69 application. Returned echoes from single or integrated multiple targets can be converted to

70 target size or density. Such conversions rely on knowing the conversion factor, or target

71 strength (TS), which is the power of the echo returned from an individual of the target type

72 of a specific size. TS depends on the cross-sectional area impacted by the advancing sound

73 wave and hence the body size and existence and form of a swim bladder, which is the main

74 sound scatterer in fishes. The swimming aspect of the fish is also a key determinant of

75 returned echo power. Returned echoes are typically displayed and analyzed on an

76 echogram, which depicts the water column, detected targets and bottom substrate, and

77 forms the basis for editing, noise or interference removal, and determination of target type

78 (Figure 1). Targets isolated as single organisms in sequential transmissions may be singled

79 out using tracking algorithms and counted. In many cases, however, the majority of targets

80 cannot be isolated, for example from schooling fishes, in which case echo integration uses

81 the average backscatter within a given volume to estimate density. More complete

82 descriptions of scientific hydroacoustics are referred to Simmonds and MacLennan (2005) 
83 and Kalikhman and Yudanov (2006), and relevant online resources from acoustics

84 technology manufacturers (HTI 2015; BioSonics 2016).

Progress in the use of hydroacoustics for the study of fish populations has been substantial over the past few decades, particularly in marine ecosystems. Scientific-grade

87 calibrated echosounders have been utilized for decades in marine environments to quantify

88 the distribution and abundance of many species of fishes and plankton (e.g., Sund 1935;

89 Thorne 1983; Pieper and Holliday 1984; Hampton 1987). The advantages of hydroacoustic

90 methods relative to capture netting are well known, and include coverage of much more of

91 the water column, especially pelagic regions where netting is often problematic, less size

92 selectivity, and non-lethality (MacLennan 1992; Simmonds and MacLennan 2005). In

93 addition, the abilities of digital and multi-frequency echosounders to assess a much broader

94 range of organism sizes and spatial and temporal distributions within the water column than

95 is feasible with net technology is now well established (Latour et al. 2003; Koslow 2009;

96 Trenkel et al. 2011). In freshwater ecosystems, hydroacoustic applications have also made

97 major methodological advances (e.g. Wanzenbock et al. 2003; Everson et al. 2013;

98 Wheeland and Rose 2014), albeit arguably less so than in marine ecosystems. With most

99 reviews and textbooks on the topic of hydroacoustics focusing on marine applications

100 (Johannesson and Mitson 1983; Simmonds and MacLennan 2005, Kalikhman and Yudanov

101 2006), the extent and scope of freshwater applications of hydroacoustics worldwide has

102 received far less attention, despite the importance of freshwater fisheries globally (Lynch et

103 al. 2016). 
104 The objective of the present study is to provide a global review of published

105 freshwater hydroacoustic research on fish and fisheries. The review is not an attempt at a 106 synthesis of results or technical aspects of hydroacoustics studies, but of their ecological

107 scope through the lenses of space (global geography - single water bodies to catchments,

108 watersheds and regions), time (one-time or seasonal surveys to long-term monitoring), and

109 taxonomy (single species to ecological communities and higher orders of taxonomic

110 organization such as genera and families). A summary of acoustic TS research on

111 freshwater species is also compiled. We did not include grey literature reports, conference

112 proceedings, laboratory or simulation studies, or non-English language publications. In

113 total, 296 studies that focused on 294 freshwater ecosystems were reviewed.

\section{Spatial Scope of Freshwater Hydroacoustics Research to Date}

115 Hydroacoustic research in freshwater ecosystems has largely been clustered in more

116 affluent countries. By far the most published literature comes from studies in North

117 America and Northern and Central Europe (Figure 2). Other important work has been

118 undertaken in Australia, China, and the East African Rift Valley, with a minority of studies

119 in South America, Russia, and New Zealand.

$120 \quad$ North America

The Pacific Northwest region of the United States and Canada is a hotspot for such

122 studies, a result of the economic importance of anadromous salmonids in the region. For

123 example, sockeye salmon (Oncorhynchus nerka) in Lake Washington have been studied

124 extensively using hydroacoustics since the 1970s (Thorne and Dawson 1974; Eggers 1978; 
125 Thorne 1979), and the Columbia River has received similar attention for its salmonid 126 species that have been impacted by widespread hydroelectric development (Johnson et al. 127 1992; Skalski et al. 1993; Steig and Johnston 1996; Johnson and Moursund 2000). Ransom 128 et al. (1998) reviewed side-aspect monitoring of salmonid (Oncorhynchus and Salmo spp.) 129 escapement in European (Finland and the UK) and Pacific North American rivers. Such 130 studies have been undertaken on more than 14 rivers in order to better understand salmon 131 population dynamics and local adaptation (Fraser et al. 2011). Some of this research has 132 addressed important ecological questions. For example, Beauchamp et al. $(1997,1999)$ 133 studied abundance, diel distribution, and predator-prey dynamics of salmonids in 134 Washington and Idaho.

The only other well-studied area of North America is the Great Lakes region, with 136 important fisheries for whitefish (Coregonus spp.), alewife (Alosa pseudoharengus), and 137 smelt (Osmerus mordax). Hydroacoustic methods are used across the Great Lakes by 138 several management agencies, and standard operating procedures are in place for 139 undertaking hydroacoustic fisheries surveys (Rudstam et al. 2009). Smelt body size has 140 been estimated for Lake Erie based on in situ TS experiments (Rudstam et al. 2003); other 141 studies on that lake have focused on cluster sampling techniques (Conners and Schwager 142 2002) and density estimates based on single vs. split-beam hydroacoustic data (Rudstam et 143 al. 1999).

144 Lake Huron is the site of smelt, alewife, bloater (Coregonus hoyi) and cisco 145 (Coregonus artedi) fisheries, and several surveys have estimated the abundance of these 146 species (Argyle 1982; Dunlop et al. 2010). Hydroacoustic fisheries research on Lake 
147 Ontario has been limited to studies on target-strength characterization of alewives (Warner 148 et al. 2002) and the effects of power plants on fish communities (Kelso and Minns 1975; 149 Ross et al. 1993). The majority of Great Lakes hydroacoustics research has been carried out on Lakes

151 Superior and Michigan. Lake Superior has fisheries for species similar to those in Lake 152 Huron with the addition of the kiyi (Coregonus kiyi - a species extirpated from other Great 153 Lakes, (COSEWIC 2005)), and extensive abundance and biomass estimates for several 154 species have been made there (Heist and Swenson 1983; Mason et al. 2005; Stockwell et al. 155 2006; Yule et al. 2007, 2008). Diel vertical migrations are exhibited by most of the native 156 pelagic forage fishes in Lake Superior and have been the focus of much attention (Hrabik et 157 al. 2006; Jensen et al. 2006; Stockwell et al. 2007), while other studies have focused on 158 spatial and trophic interactions of forage fish and plankton (Holbrook et al. 2006). Surveys 159 have been carried out on Lake Michigan to explicitly compare fish size to TS for pelagic 160 species (Fleischer et al. 1997). Vertical migrations have been investigated in alewives 161 (Janssen and Brandt 1980) and bloaters (Fleischer and Tewinkel 1998, 1999). Additional 162 studies have been undertaken to improve survey design (Fabrizio et al. 1997; Argyle 1992; 163 Adams et al. 2006) and to understand how fish react to heat effluents from Lake Michigan 164 power plants (Spigarelli et al. 1973, 1982). General surveys to measure density and 165 abundance were carried out on Lake Michigan as well (Peterson et al. 1976; Brandt et al. 166 1991).

167 Other water bodies in North America with multiple published hydroacoustic studies 168 include Lakes Croche (Gauthier et al. 1997; Gaudreau and Boisclair 1998, 2000), Mendota 
169 (Hasler and Villemonte 1953; Hergenrader and Hasler 1967; Rudstam et al. 1987), Oneida

170 (Arrhenius et al. 2000; Rudstam et al. 2002) and Texoma (Van Den Avyle et al. 1995;

171 Degan and Wilson 1995; Vondracek and Degan 1995). More recent research on the

172 salmonids Brook Charr (Salvelinus fontinalis) and Ounaniche (landlocked Atlantic Salmon

173 Salmo salar) in Newfoundland ponds has indicated potential to isolate and measure

174 individual fish (Figure 1).

\section{Europe}

176 In Europe, freshwater hydroacoustic applications are well established in southern

177 Scandinavia, the methods having been adapted from marine fisheries applications in the

178 region, which routinely use hydroacoustic data for fisheries management. Abundance

179 estimates in Norway and Sweden have been undertaken in multiple freshwater systems

180 (Brabrand 1991; Linløkken 1995; Balk and Lindem 2000; Romakkaniemi et al. 2000) for

181 species including Atlantic salmon, Arctic charr (Salvelinus alpinus), whitefish, and vendace

182 (Coregonus albula). Several authors (Romakkaniemi et al. 2000; Romare 2001; Knudsen

183 and Sægrov 2002) investigated the benefits of using horizontal echo sounding

184 complementary to the more common vertical sounding for abundance and behavioral

185 studies. They found that horizontal beaming, combined with vertical acoustics, provided

186 more complete estimates of abundance by allowing researchers to observe fish near the

187 surface and in littoral zones closer to shore. Vertical migrations in coregonids (Gjelland and

188 Bohn 2004; Knudsen and Gjelland 2004) and vendace (Hamrin 1986) have been well

189 studied in Scandinavia. Other studies have compared fish echo traces with those of pelagic

190 invertebrates (Knudsen and Larsson 2009; Knudsen et al. 2006), studied factors affecting 
191 recruitment variability (Axenrot and Degerman 2016), and have investigated effects of 192 introduced species (Brabrand and Faafeng 1993) and climate change (Nyberg et al. 2001) 193 on aquatic systems.

(Lilja et al. 2000) studied TS of Atlantic salmon, brown trout (Salmo trutta),

195 whitefish and pike (Esox lucius) in Finland (see Table 1), where extensive work has been

196 done on fish abundance estimates (e.g. Jurvelius and Sammalkorpi 1995; Jurvelius et al.

197 1984). Several studies have compared the different methods of estimating abundance on

198 Finnish lakes, including electrofishing depletion, gillnetting, seining, trawling, and

199 hydroacoustics (Auvinen and Jurvelius 1994; Horppila et al. 1996; Jurvelius et al. 2010).

200 These studies concluded that hydroacoustic surveys must account for seasonal variability in

201 fish behavior and habitat use to provide comparable measures of fish distribution and

202 abundance. Vertical migrations of fish have been the focus of many Finnish researchers as

203 well (Sydanoja et al. 1995; Jurvelius and Marjomaki 2004, 2008; Kahilainen et al. 2004;

204 Malinen and Tuomaala 2005). Valuable long-term studies of vendace density have been

205 performed on Lake Puulavesi (Marjomaki and Huolila 1995, 2001).

206 The UK and northern mainland European countries such as France, Germany,

207 Poland and the Czech Republic are active areas for freshwater hydroacoustics research. In

208 the UK, one well-studied system is Lake Windermere, with extensive research on Atlantic

209 salmon and Arctic charr having taken place there (Baroudy and Elliott 1993; Elliott et

210 al.1996; Elliott and Fletcher 2001; Jones et al. 2008; Winfield et al. 2002, 2007, 2015).

211 Winfield et al. (2009) assessed Arctic charr abundance in five Scottish lochs as well. Lake

212 studies in other areas of the UK have examined spatial distribution and patchiness of fish 
213 (Duncan and Kubecka 1996; George and Winfield 2000), the distribution of juvenile perch

214 (Perca fluviatilis, Goldspink 1990), target-strength body-size relationships for brown trout

215 (Salmo trutta), rainbow trout (Oncorhynchus mykiss), Atlantic salmon, roach (Rutilus

216 rutilus), perch, dace (Leuciscus leuciscus), chub (Leuciscus cephalus), crucian and common

217 carp (Carassius carassius and Cyprinus carpio), bleak (Alburnus alburnus) and bream

218 (Abramis brama) (Kubecka and Duncan 1998, Table 1), and have estimated brown trout

219 populations in several localities (Kubecka et al. 1994).

220 UK researchers have also been at the forefront of hydroacoustics research in lotic

221 systems. Studies using both mobile and fixed-transducer techniques have been used in

222 rivers such as the Rivers Thames (Hughes 1998; Kubecka and Duncan 1998b), Ouse (Frear

223 2002), Trent (Lyons 1998), Hull (Peirson and Frear 2003) and Wye (Nealson and Gregory

224 2000). Ireland has been the site of surveys for pollan (Coregonus autumnalis - Rosell 1997;

225 Harrison et al. 2010) and a study of interactions between fish and plankton (Wojtal-

226 Frankiewicz et al. 2009).

Hydroacoustic surveys in France have been undertaken on the Seine (Guillard et al.

228 1994) and Rhône (Guillard and Colon 2000) rivers, as well as on Lakes Pareloup (Brosse et

229 al. 1999), Bourget (Guillard and Gerdeaux 1993) and Chalain (Guillard and Vergès 2007).

230 Lake Annecy has been studied over a long period of time, with extensive focus on seasonal

231 and ontogenetic changes in fish assemblages (Masson et al. 2001; Guillard et al. 2004,

232 2006a, 2006b, 2010;). The most important fish species in these areas are European

233 whitefish (Coregonus lavaretus), common roach and European perch. 
In Germany, several authors have researched fish communities in reservoir systems.

235 For example, avoidance behavior of vendace has been studied on the Bigge reservoir

236 (Schmidt and Gassner 2006; Schmidt 2009), while abundance estimates of vendace and

237 whitefish were conducted in the Henne and Wahnbach Reservoirs, respectively (Brenner et

238 al. 1987; Schmidt et al. 2005). Lake Constance is a well-studied system where diel vertical

239 migrations of European perch and burbot (Lota lota) have been characterized (Imbrock et

240 al. 1996; Probst and Eckmann 2009). Seasonal variations in fish schooling and migration

241 in perch and whitefish have drawn attention in other studies (Eckmann and Imbrock 1996;

242 Ptak and Appenzeller 1998).

Lake Stechlin is the most well studied lake in Germany, owing to the presence of

244 the Leibniz Institute of Freshwater Ecology and Inland Fisheries on its shores.

245 Hydroacoustic research there has been extensive, focusing largely on the reliability of

246 acoustic fish population estimates (Wanzenbock 2003; Mehner et al. 2003, 2005, 2007;

247 Mehner 2006a; Busch and Mehner 2009) and comparison with other stock estimation

248 techniques such as gillnetting and trawling (Mehner and Schulz 2002; Mehner 2006b;

249 Emmrich et al. 2010), all of which determined the methods to be complementary and

250 comparable (although gillnetting tended to underestimate $0+$ fish that were too small for the

251 mesh). Vertical migrations of pelagic fishes have been characterized on Lake Stechlin as

252 well (Mehner 2006a; Mehner et al. 2010).

In Poland, hydroacoustic research has been conducted for many years. Lake Pluszne

254 has been subject to studies of abundance (Doroszczyk et al. 2007), vertical distributions

255 (Dembinski 1971; Świerzowski 2001), fish coexistence with blue-green algae (Godlewska 
256 et al. 2015), comparisons of multiple frequencies (Godlewska et al. 2009a), and the effects

257 of seasonal changes on abundance estimates (Świerzowski and Godlewska 2001;

258 Świerzowski and Doroszczyk 2004). Many studies in Poland have been relatively long-

259 term and include multiple bodies of water (Dembinski 1971; Godlewska and Swierzowski

260 2003; Doroszczyk et al. 2007; Godlewska et al. 2009b).

261 Hydroacoustic research has been carried out on reservoir systems in the Czech

262 Republic. The most intensively studied reservoir in the region is the Rimov Reservoir, a

263 heavily managed system that provides drinking water and recreational fisheries for much of

264 the southern portion of the country. Research at the Rimov has been diverse, with studies

265 ranging from survey differences resulting from horizontal versus vertical beaming

266 (Kubecka and Wittingerova 1998; Tušer et al. 2009), fish swimming behavior (Čech and

267 Kubecka 2002), spatial distributions (Vašek et al. 2004; Prchalová et al. 2009), to boat

268 avoidance (Draštík and Kubečka 2005) and ontogenetic changes in fish distribution (Čech

269 and Kubečka 2006). Diel migrations (Čech et al. 2005), daytime versus nighttime

270 abundance estimates (Draštík et al. 2009), and juvenile perch distribution and abundance

271 (Kubecka and Svatora 1993; Frouzova and Kubecka 2004; Čech et al. 2005, Čech et al.

272 2007) have been examined. The only study that has attempted to draw generalizations and

273 comparisons spatially across different regions of Europe by studying lakes from multiple

274 watersheds was carried out by (Emmrich et al. 2012). This study found robust compatibility

275 between gillnetting and hydroacoustic surveys in a diversity of systems in Norway,

276 Sweden, Denmark, the UK, Germany, France and Italy. 
Beyond Europe and North America, another well-studied area is the African Rift Valley

280 and Great Lakes, including Victoria, Malawi and Kivu. The sustainability of Lake Kivu's

281 fishery for the introduced Tanganyika sardine (Limnothrissa miodon) has been assessed

282 (Guillard et al. 2012), and the diet and feeding behavior of pelagic fish studied using a

283 combination of stomach content analysis and hydroacoustic surveys in Lake Malawi

284 (Allison et al. 2008). Lake Victoria has been the focus of considerable hydroacoustic

285 survey effort in recent years - likely the result of the introduced Nile perch (Lates niloticus)

286 and declining cichlid populations (e.g. Ogari and Dadzie 1988). TS measurements and

287 distribution related to stratification have been reported for the Nile perch (Goudswaard et

288 al. 2004; Kayanda et al. 2012; Taabu-Munyaho et al. 2013). The spatial and temporal

289 variation in distribution has also been studied for cichlids (Getabu et al. 2003; Tumwebaze

290 et al. 2007; Taabu-Munyaho et al. 2014). Looking forward, Everson and colleagues (2013a,

291 b) have suggested using hydroacoustics in Lake Victoria to establish ecosystem-based

292 fisheries management.

$293 \quad$ Asia

294 Most of the hydroacoustic work in Asia has been conducted in China, where the onset of

295 large hydroelectric megaprojects has resulted in some of the few published hydroacoustic

296 studies from this continent - many more may not be reported in the English language

297 literature. The Yangtze River has been the site of most of this work. Studies on large fishes

298 such as common carp and the endangered Chinese sturgeon (Acipenser sinensis) and 
299 paddlefish (Psephurus gladius) (Qiao et al. 2006; Zhang et al. 2009, Zhang et al. 2011;

300 Wang et al. 2013) have been the focus, although some authors have broadened their work

301 to other species (Tao et al. 2010; Lin et al. 2013a, b). Other systems studied through

302 hydroacoustics in China include the Pearl River (Tan et al. 2011) and Lake Laojianghe (Ye

303 et al. 2013).

304 Other Regions

305 Hydroacoustic research on inland fisheries in areas other than those outlined above

306 has been far less extensive, although some important work has taken place in Argentina

307 (Oldani and Baigun 2002; Vigliano et al. 2008, 2009), Australia (Matveev 2003, Matveev

308 2007), Brazil (Loures and Pompeu 2015), Iceland (Snorrason et al. 1992), Israel (Walline et

309 al. 1992); Kalikhman et al. 1992; Horne et al. 2000), Japan (Okamoto et al. 1993; Iida and

310 Mukai 1995; Mukai and Iida 1996; Trevorrow 1996; Haga et al. 2007), Mali (Coll et al.

311 2007), New Zealand (Rowe 1994; Rowe and Chisnall 1995), Russia (Pavlov et al. 1986;

312 Borisenko et al. 2006; Mochek et al. 2015), Spain (Rodríguez-Sánchez et al. 2015),

313 Thailand (Prchalova et al. 2003), Tunisia (Djemali et al. 2009, Djemali et al. 2010) and

314 Zimbabwe (Begg 1976). Although these studies are widespread, many important

315 watersheds have been untouched by hydroacoustics research globally.

316 Most hydroacoustic surveys and research has focused on a single body of water

317 (Figure 3). A few studies have investigated multiple systems. For example, (Emmrich et al.

318 2010) studied 18 lakes in seven different European countries, and based on these

319 comparisons were able to provide evidence on the correspondence of gillnet catches with 
320 hydroacoustics across the entire region. Another author was able to make broad

321 comparisons of 11 freshwater systems in Australia and North America in studies of food

322 web theory (Matveev 2003). Overall, however, generalization of patterns observed in

323 hydroacoustic data may be constrained by the clustered distribution of studies which may

324 lead to lakes within a cluster being pseudoreplicates. A broader spatial distribution of data

325 would help resolve this problem and enable larger-scale spatial data comparisons and meta-

326 analyses. Although we emphasize the need to fully understand the acoustic properties of

327 species of interest prior to undertaking larger-scale studies (Kubečka et al. 2009), a lack of

328 broader spatial coverage reduces the possibility of uncovering important differences and

329 dynamics between water bodies, including variations in fish reproductive success and

330 timing (Leggett and Carscadden 1978; Jackson et al. 2001), and seasonal and daily

331 movement patterns among lakes and rivers (Winemiller and Jepsen 1998; Woolnough et al.

332 2009). The limited number of water bodies and geographic scope covered to date by

333 hydroacoustic survey methods reviewed here has important consequences beyond spatial

334 representation; this will be explored in the coming sections.

\section{Taxonomic Scope of Freshwater Hydroacoustics Research}

336 One consequence of the lack of spatial coverage of hydroacoustic studies is the

337 limited number of taxa that have been researched. Globally, estimates of the number of

338 extant freshwater fish species lie somewhere around 15000 if anadromous species are

339 included, in about 170 families (Leveque et al. 2008). The current review documents

340 approximately 109 species in 32 families (Figure 4) that have been studied using

341 hydroacoustics $(0.0073 \%$ of total species diversity and $18.8 \%$ of family diversity). 
342 Following marine applications, the majority of research has focused on commercially

343 valued taxa, in particular Salmonids, Cyprinids, Percids, Osmerids and Clupeids (Figure 5).

344 Studies on these taxa accounted for over $85 \%$ of all reported research in this area. Three

345 commercially important European species - roach, perch, and vendace - are the focus of the

346 majority of studies undertaken, and in many cases other fishes are only included

347 incidentally (though they may be ecologically important).

348 The limited overall taxonomic coverage indicates that factors that may affect

349 hydroacoustic properties have been studied in very few freshwater species. Such detailed

350 species-focused studies are necessary in order to determine individual behavioral traits such

351 as vessel avoidance (Wheeland and Rose 2014), physiological traits and TS-length

352 relationships (Ona 1990), and variation in TS as a result of changes in aspect of the fish

353 within an acoustic beam (Kubečka 1994), all of which can affect size and density estimates.

354 Hydroacoustic studies should ideally include fish length-TS research to ensure that the

355 relationship used for length or biomass calculations is locally appropriate for the studied

356 species. To date, such studies are rare, with TS quantified for only 21 species (Table 1).

The TS data for freshwater fishes indicate that the traditional "standard" formula for

358 TS-length models $\left(\mathrm{TS}_{\mathrm{dB}}=20 \log _{10}\left(\right.\right.$ length $\left.\left._{\mathrm{cm}}\right)-\mathrm{b}\right)($ Simmonds and MacLennan 2005), which

359 assumes that the scattering area and hence backscatter is proportional to the square of fish

360 length, is not appropriate for many or most species (Table 1). It is also apparent that

361 substantial and unexplained variability exists in the proposed models, which might result

362 from several factors, including site, seasonal or condition factors of the studied fishes (Ona

363 1990; Rose 1992), in addition to frequency and methodical differences among studies. 
364 Target strength models based on fish length plotted from data in Table 1 show

365 substantial variation (Figure 6). Differences are apparent within species and families and

366 among frequencies, although the differences are inconsistent. Few correspond to the

367 "standard" form that assumes a quadratic relationship to length (Simmonds and MacLennan

368 2005), which tends to support contentions based on marine fish that the standard form is the

369 exception (McClatchie et al. 1996). When frequency and species are taken into account, the

370 models appear to be more similar, although differences are still apparent. For example, for

371 Coregonids (Figure 6a), all measured at $120 \mathrm{kHz}$, two independent models are near

372 identical, but for a different but closed related species the model differs substantially. Large

373 differences are apparent in the two models for Clupeids (Figure 6c), although these are

374 confounded by different frequencies and a mix of species in the model of Fleischer et al.

375 (1997). Models for Cyprinids (Figure 6d) are more tightly grouped, but again there are

376 differences among species and frequencies that are not entirely consistent. Some species

377 show higher TS at $200 \mathrm{kHz}$ than at $420 \mathrm{kHz}$ which is consistent with theory, but there are

378 exceptions to that with data mostly from Carassius carassius, although even this

379 comparison is confounded by a mix of different species. The most inconsistent TS models

380 have been derived from side aspect studies, shown for Salmonids having similar body

381 forms (Figure 6b). It appears that $200 \mathrm{kHz}$ models predict higher TS than those at $420 \mathrm{kHz}$,

382 but the single model at $120 \mathrm{kHz}$ is in the middle with slope lower than other models and the

383 standard form (most models are higher). These inconsistencies lead us to caution

384 researchers against transference of TS models across species or frequencies, and to 
385 conclude that more work is needed in this area if TS models are to be used to estimate 386 biomass.

In terms of the taxa that have been studied, by far the most well-studied group is the salmonids - not only anadromous Oncorhynchus and Salmo spp., but also landlocked Salvelinus (charr) and Coregonus (whitefish and cisco) spp. Other families that are well-

390 studied include the cyprinids, perch, smelts, and herring, although in most cases very few

391 individual species have been studied within a family (Figures 4 and 5).

A disproportionate amount of TS research has been undertaken on three European

393 species in particular - roach, European perch (Perca fluviatilis) and the vendace or

394 European cisco (Coregonus albula). These species are dominant and widespread in

395 Northern and Central Europe with active fisheries throughout the region, and more than a quarter of the literature reviewed here involved one or more of these species.

The heavy concentration of hydroacoustic studies on these taxa leaves large gaps in

398 our knowledge of other important freshwater taxa. Many groups that include commercially

399 and ecologically important species have so far not been studied. Some morphologically

400 disparate or diverse groups are yet to be investigated, and it is unclear how various physical

401 differences will impact echo interpretation and subsequent hydroacoustic abundance

402 estimates. Further progress on species identification through hydroacoustics will depend

403 on an improvement in our knowledge of how acoustic signatures vary among species with

404 differing morphologies and ecological niches (Horne 2000). 
An alternative to the single species approach is to measure acoustic size rather than

406 species and construct abundance size spectra from hydroacoustic data, which can allow for

407 fish counts or estimates of biomass at various trophic levels and thus insights into system

408 structure and dynamics (Pollom and Rose 2015; Wheeland and Rose 2016; de Kerckhove et

409 al. 2016). Taking this approach alleviates the necessity of identifying and classifying

410 species within the hydroacoustic record, in cases in which the majority of individuals can

411 be isolated within the acoustic beam and detectable as single targets. Especially where

412 densities disallow reliable counting of individuals, echo integration may enable more size

413 spectra indicators (de Kerckhove et al. 2016).

\section{Temporal Scope of Freshwater Hydroacoustics Research to Date}

415 One of the most promising avenues for freshwater hydroacoustics is long-term

416 monitoring. Long-term (multiple seasons or years) monitoring of fish stocks is required in

417 order to disaggregate seasonal variation and trends in populations caused by natural or

418 anthropogenic environmental change. This literature review indicates that long-term

419 hydroacoustic studies are rare in the literature, with most studies having taken place within

420 a single year (often only through a few surveys done over months or weeks, and even only

421 days in many cases - Figure 6). $63 \%$ of the studies reviewed here were conducted in one

422 full year or less, and $75 \%$ of studies within two years or less. Only $12 \%$ of studies endured

423 for five or more years, and very few had a duration of $>10$ years, which would arguably be

424 the smallest window needed to uncover important year-to-year and seasonal variability. The

425 majority of published studies were thus essentially snapshots of an aquatic ecosystem and

426 fish population, and may have missed important phenological events that are crucial to 
427 understanding such systems and predicting fisheries performance (e.g. Jeppesen et al. 428 2012).

Longer-term studies have potential to reveal ecosystem and target species dynamics

430 that are impossible with single year or season studies. Moreover, longer-term research

431 enables evaluations of survey characteristics and error, and allows comparisons to

432 environmental and anthropogenic variables. For example, Godlewska et al. (2009b) studied

433 Polish lakes for 76 months and were able to estimate the relationship between sampling

434 intensity and survey precision. That study showed a sampling error of less than $10 \%$ when

435 coverage of the water body was sufficient $(\sim 2)$. Other advantages of long-term studies

436 include the ability to assess seasonal variability (Winfield et al. 2007) and to observe long-

437 term population dynamics (Brabrand and Faafeng 1993; Johnson and Goettl 1999;

438 Marjomaki and Huolila 2001).

439 In all ecological studies, longer-term data tend to give a more complete picture of

440 how communities and ecosystems change over time, allowing for a more adaptive approach

441 to management that can help to avoid the pitfalls of shifting baselines in fishery knowledge

442 and to better manage freshwater resources (Pauly 1995). Early warning signs of

443 anthropogenic impacts and unwanted ecological changes are easier detected with

444 monitoring in place as well, and such datasets allow for the disentangling of how biotic,

445 abiotic, and spatial factors affect fish abundance estimates (Jackson et al. 2001). 


\section{$446 \quad 1.5$ Challenges}

447 Perhaps the biggest challenge in quantitative fisheries hydroacoustics has been the

448 identification of studied targets to some taxonomic level useful for management and

449 research (e.g., Rose and Leggett 1988; Lu and Lee 1995; Scalabrin et al. 1996; Haralabous

450 and Georgakarakos 1996). Much progress in identification has been made in marine

451 environments since those early studies (Horne 2000; Lawson et al. 2001; Kang et al. 2002;

452 Robotham et al. 2010), and the advent of acoustic broadband methods that allow for high-

453 resolution imagery of fish and their swimbladders holds promise (Stanton et al. 2010).

454 There has been less focus on this type of research in freshwater, where acoustic signal

455 characteristics of various species are still relatively poorly known. It is noteworthy,

456 however, that the complexities of identification, especially in species-rich ecosystems, may

457 be overcome using size and not species as the basis for characterizations of freshwater fish

458 communities (Pollom and Rose 2015; Wheeland and Rose 2015; de Kerckhove et al. 2016).

459 One promising acoustic tool in terms of species identification is the dual-frequency

460 identification sonar (DIDSON), which utilizes high frequencies and a more structured beam

461 array to resolve morphology. The technique is most widely deployed from a fixed

462 transducer in shallow riverine environments that allow passing fish to be counted (e.g.

463 Mueller et al. 2010; Langkau et al. 2012; see Martignac et al. 2014 for a review and Tušer

464 et al. 2014 for potential biases). DIDSON methods can also be deployed simultaneously

465 with side-scan sonar in order to emit sound horizontally for the purposes of studying

466 shallow or littoral zones (Hughes and Hightower 2015). 
Another major challenge in freshwater hydroacoustic fisheries research is the

468 limitations imposed by turbulent water (i.e. fast-moving sections of river) and shallow

469 littoral regions of a watershed, which usually encompass most of higher-order streams and

470 tributaries (Simmonds and MacLennan 2005). These limitations are caused by

471 reverberations, scattering, and absorption of acoustic waves by air bubbles and sediments

472 that are suspended in turbulent water and obscure fish targets (Trevorrow 1998).

473 Nonetheless, many successful hydroacoustic monitoring programs in such environments

474 have been conducted, particularly on migrating salmonids, with progress made in species

475 identification and size estimations (Ransom et al. 1998; Banneheka et al. 2011). Noise

476 reduction techniques such as cross-filtering between echograms have shown promise in

477 such environments (Balk and Lindem 2000).

478 A logistic challenge in the advancement of freshwater monitoring programs in much

479 of the developing world, where fisheries are of particular importance (Lynch et al. 2016),

480 and where hydroacoustics could play an important role, is the lack of available equipment

481 and trained personnel. In countries where hydroacoustic applications are well developed,

482 progress in limiting these shortcomings can be made (and has been in some cases, e.g. Lake

483 Victoria) by encouraging advanced training, collaboration, and re-use of older

484 hydroacoustic equipment.

\section{Summary and Conclusions}

This review revealed substantial expansion and progress in freshwater

487 hydroacoustics since the earliest implementations, with applications in 42 countries. 124 
488 fish species have been investigated, although only 21 intensively so, and in a limited

489 number of water bodies with concentrations in North America and Europe. There have been

490 relatively few long-term (more than a decade) studies. It is thought that more

491 comprehensive temporal, geographical and taxonomic coverage would elevate knowledge

492 of freshwater ecosystems and fisheries dynamics. In addition, the acoustic properties of

493 most freshwater species remain poorly known, even for some species that have been

494 studied intensively. Further research on the backscatter characteristics and acoustic TS of

495 these and other species are required to enhance the quantitative aspects of hydroacoustic

496 surveys. At the same time, recent size-based monitoring that may be particularly relevant to

497 freshwater ecosystems and fisheries and does not require species identification should be

498 further explored as an alternative to traditional species-based approaches. Overall a more

499 systematic approach to the use of hydroacoustics in freshwater ecosystems shows promise

500 in helping to fulfill the goal of sustainable ecosystem-based fisheries management for

501 inland fisheries globally.

\section{Acknowledgments}

503 Funding was received from the Natural Sciences and Engineering Research Council

504 (NSERC) and Manitoba Hydro through the Hydronet Network, and from NSERC

505 Discovery grants to GAR. Xiong Zhang provided valuable insight into the hydroacoustics

506 work being carried out in China. Earlier reviews by Daniel Boisclair, Marie Clement,

507 Rodolphe Devillers, and Brian Shuter, and two more recent anonymous reviews, were of

508 great help in bringing this manuscript to completion. 


\section{References}

510

511

512

513
Adams, J. V., Argyle, R.L., Fleischer, G.W., Curtis, G.L. and Stickel, R.G. 2006. Improving the design of acoustic and midwater trawl surveys through stratification, with an application to Lake Michigan prey fishes. North Am. J. Fish. Manag. 26: 612621. doi:10.1577/M04-216.1.

Allison, E.H., Irvine, K., Thompson, A.B. and Ngatunga, B.P. 2008. Diets and food consumption rates of pelagic fish in Lake Malawi, Africa. Freshw. Biol. 35: 489-515. doi:10.1111/j.1365-2427.1996.tb01764.x.

Argyle, R.L. 1982. Alewives and rainbow smelt in Lake Huron: Midwater and bottom aggregations and estimates of standing stocks. Trans. Am. Fish. Soc. 111: 267-285. doi: 10.1577/1548-8659(1982)111<267:AARSIL>2.0.CO;2.

Argyle, R.L. 1992. Acoustics as a tool for the assessment of Great Lakes forage fishes. Fish. Res. 14: 179-196. doi:10.1016/0165-7836(92)90052-U.

Arrhenius, F., Benneheij, B.J.A.M., Rudstam, L.G. and Boisclair, D. 2000. Can stationary bottom split-beam hydroacoustics be used to measure fish swimming speed in situ? Fish. Res. 45: 31-41. doi:10.1016/S0165-7836(99)00102-2.

Auvinen, H. and Jurvelius, J. 1994. Comparison of pelagic vendace (Coregonus albula) stock density estimation methods in a lake. Fish. Res. 19: 31-50. doi:10.1016/01657836(94)90013-2.

Van Den Avyle, M.J., Boxrucker, J., Michaletz, P., Vondracek, B. and Ploskey, G.R. 1995. 
Comparison of catch rate, length distribution, and precision of six gears used to sample reservoir shad populations. North Am. J. Fish. Manag. 15: 940-955. doi:10.1577/1548-8675(1995)015<0940:COCRLD>2.3.CO;2.

Axenrot, T. and Degerman, E. 2016. Year-class strength, physical fitness and recruitment cycles in vendace (Coregonus albula). Fish. Res. 173: 61-69. doi:10.1016/j.fishres.2015.03.017

Balk, H. and Lindem, T. 2000. Improved fish detection in data from split-beam sounder. Aquat. Living Resour. 13: 297-303. doi:10.1016/S0990-7440(00)01079-2.

Banneheka, S.G., Routledge, R.D., Guthrie, I.C. and Woodey, J.C. 2011. Estimation of inriver fish passage using a combination of transect and stationary hydroacoustic sampling. Can. J. Fish. Aquat. Sci. 52: 335-343. doi:10.1139/f95-034.

Baroudy, E. and Elliott, J.M. 1993. The effect of large-scale spatial variation of pelagic fish on hydroacoustic estimates of their population density in Windermere (northwest England). Ecol. Freshw. Fish 2: 160-166. doi:10.1111/j.1600-0633.1993.tb00098.x.

Beauchamp, D.A., Baldwin, C.M., Vogel, J.L. and Gubala, C.P. 1999. Estimating diel, depth-specific foraging opportunities with a visual encounter rate model for pelagic piscivores. Can. J. Fish. Aquat. Sci. 56: 128-139. doi:10.1139/f99-217.

Beauchamp, D.A., Luecke, C., Wurtsbaugh, W.A., Gross, H.G., Budy, P.E., Spaulding, S., Dillenger, R. and Gubala, C.P. 1997. Hydroacoustic assessment of abundance and diel distribution of sockeye salmon and kokanee in the Sawtooth Valley Lakes, Idaho. 
North Am. J. Fish. Manag. 17: 253-267. doi:10.1577/15488675(1997)017<0253:HAOAAD>2.3.CO;2.

Begg, G.W. 1976. The relationship between the diurnal movements of some of the zooplankton and the sardine Limnothrissa miodon in Lake Kariba, Rhodesia. Limnol.

Borisenko, E.S., Degtev, A.I., Mochek, A.D. and Pavlov, D.S. 2006. Hydroacoustic Oceanogr. 21: 529-539. doi:10.4319/1o.1976.21.4.0529.

BioSonics, Inc. 2016. Fisheries stock assessment - How it works [Online]. Available from $\underline{\text { http://www.biosonicsinc.com/applications-fisheries-stock-assessment.asp\#howitworks }}$ [Accessed 03-May-2016].

characteristics of mass fishes of the Ob-Irtysh Basin. J. Ichthyol. 46: S227-S234. doi:10.1134/S0032945206110130.

Brabrand, A. 1991. The estimation of pelagic fish density, single fish size and fish biomass of Arctic charr (Salvelinus alpinus (L.)) by echosounding. Nord. J. Freshw. Res. 66, $44-49$

Brabrand, Å. and Faafeng, B. 1993. Habitat shift in roach (Rutilus rutilus) induced by pikeperch (Stizostedion lucioperca) introduction: predation risk versus pelagic behaviour. Oecologia 95: 38-46. doi:10.1007/BF00649504.

Brandt, S.B., Mason, D.M., Patrick, E.V., Argyle, R.L., Wells, L., Unger, P.A. and Stewart, D.J. 1991. Acoustic measures of the abundance and size of pelagic planktivores in Lake Michigan. Can. J. Fish. Aquat. Sci. 48: 894-908. doi:10.1139/f91-106. 
Brenner, T., Clasen, J., Lange, K. and Lindem, T. 1987. The whitefish (Coregonus

570 lavaretus (L.)) of the Wahnbach reservoir and their assessment by hydroacoustic methods. Swiss J. Hydrol. 49: 363-372. doi:10.1007/BF02538296.

572

573

Brosse, S., Lek, S. and F., D. 1999. Predicting fish distribution in a mesotrophic lake by hydroacoustic survey and artificial neural networks. Limnol. Oceanogr. 44: 12931303. doi:10.4319/1o.1999.44.5.1293.

Busch, S. and Mehner, T. 2009. Hydroacoustic estimates of fish population depths and densities at increasingly longer time scales. Int. Rev. Hydrobiol. 94: 91-102. doi:10.1002/iroh.200811092.

Cech, M., Kratochvil, M., Kubecka, J., Drastik, V. and Matena, J. 2005. Diel vertical migrations of bathypelagic perch fry. J. Fish Biol. 66: 685-702. doi:10.1111/j.00221112.2005.00630.x

Cech, M. and Kubecka, J. 2002. Sinusoidal cycling swimming pattern of reservoir fishes. J. Fish Biol. 61: 456-471. doi:10.1111/j.1095-8649.2002.tb01577.x.

Čech, M. and Kubečka, J. 2006. Ontogenetic changes in the bathypelagic distribution of European perch fry Perca fluviatilis monitored by hydroacoustic methods. Biologia (Bratisl). 61: 211-219. doi:10.2478/s11756-006-0032-x.

Čech, M., Kubečka, J., Frouzová, J., Draštík, V., Kratochvíl, M., Matěna, J. and Hejzlar, J. 2007. Distribution of the bathypelagic perch fry layer along the longitudinal profile of two large canyon-shaped reservoirs. J. Fish Biol. 70: 141-154. doi:10.1111/j.1095- 
8649.2006.01282.x.

Coll, C., Morais, L.T. de, Laë, R., Lebourges-Dhaussy, A., Simier, M., Guillard, J., Josse, E., Ecoutin, J.-M., Albaret, J.-J., Raffray, J. and Kantoussan, J. 2007. Use and limits of three methods for assessing fish size spectra and fish abundance in two tropical manmade lakes. Fish. Res. 83: 306-318. doi:10.1016/j.fishres.2006.10.005.

Conners, M. and Schwager, S.J. 2002. The use of adaptive cluster sampling for hydroacoustic surveys. ICES J. Mar. Sci. 59: 1314-1325. doi:10.1006/jmsc.2002.1306.

COSEWIC 2005. COSEWIC assessment and update status report on the Lake Ontario kiyi Coregonus kiyi orientalis and Upper Great Lakes kiyi Coregonus kiyi kiyi in Canada. Committee on the Status of Endangered Wildlife in Canada. Ottawa. vi +17 p. Available at www.sararegistry.gc.ca/status/status_e.cfm.

Degan, D.J. and Wilson, W. 1995. Comparison of four hydroacoustic frequencies for sampling pelagic fish populations in Lake Texoma. North Am. J. Fish. Manag. 15: 924-932. doi:10.1577/1548-8675(1995)015<0924:COFHFF>2.3.CO;2.

Dembinski, W. 1971. Vertical distribution of vendace Coregonus albula L. and other pelagic fish species in some Polish lakes. J. Fish Biol. 3: 341-357. doi:10.1111/j.10958649.1971.tb03689.x.

Djemali, I., Laouar, H. and Toujani, R. 2010. Distribution patterns of fish biomass by acoustic survey in three Tunisian man-made lakes. J. Appl. Ichthyol. 26: 390-396. 
doi:10.1111/j.1439-0426.2009.01353.x.

610

611

612

613

614

615

616

617

618

619

620

621

622

623

624

625

626

627

628

Djemali, I., Toujani, R. and Guillard, J. 2009. Hydroacoustic fish biomass assessment in man-made lakes in Tunisia: horizontal beaming importance and diel effect. Aquat. Ecol. 43: 1121-1131. doi:10.1007/s10452-008-9215-6.

Doroszczyk, L., Dlugoszewski, B., Kanigowska, E. and Godlewska, M. 2007a. Hydroacoustic monitoring of vendace in selected Mazurian lakes. Arch. Polish Fish. 15: $129-140$.

Draštík, V. and Kubečka, J. 2005. Fish avoidance of acoustic survey boat in shallow waters. Fish. Res. 72: 219-228. doi:10.1016/j.fishres.2004.10.017.

Draštík, V., Kubečka, J., Čech, M., Frouzová, J., Říha, M., Juza, T., Tušer, M., Jarolím, O., Prchalová, M., Peterka, J., Vašek, M., Kratochvíl, M., Matěna, J. and Mrkvička, T. 2009. Hydroacoustic estimates of fish stocks in temperate reservoirs: day or night surveys? Aquat. Living Resour. 22: 69-77. doi:10.1051/alr/2009013.

Duncan, A. and Kubecka, J. 1996. Patchiness of longitudinal fish distributions in a river as revealed by a continuous hydroacoustic survey. ICES J. Mar. Sci. 53: 161-165. doi:10.1006/jmsc.1996.0017.

Dunlop, E.S., Milne, S.W. and Ridgway, M.S. 2010. Temporal trends in the numbers and characteristics of Lake Huron fish schools between 2000 and 2004. J. Great Lakes Res. 36: 74-85. doi:10.1016/j.jglr.2009.12.006.

Eckmann, R. and Imbrock, F. 1996. Distribution and diel vertical migration of Eurasian 
perch (Perca fluviatilis L.) during winter. Ann. Zool. Fennici 33: 679-686.

Eggers, D. 1978. Limnetic feeding behavior of juvenile sockeye salmon in Lake Washington and predator avoidance. Limnol. Oceanogr. 23: 1114-1125. doi:10.4319/1o.1978.23.6.1114.

Elliott, J.. and Fletcher, J.. 2001. A comparison of three methods for assessing the abundance of Arctic charr, Salvelinus alpinus, in Windermere (northwest England). Fish. Res. 53:39-46. doi:10.1016/S0165-7836(00)00270-8.

Elliott, J.M., Fletcher, J.M., Elliott, J.A., Cubby, P.R. and Baroudy, E. 1996. Changes in the population density of pelagic salmonids in relation to changes in lake enrichment in Windermere (northwest England). Ecol. Freshw. Fish 5: 153-162. doi:10.1111/j.16000633.1996.tb00128.x.

Emmrich, M., Helland, I.P., Busch, S., Schiller, S. and Mehner, T. 2010. Hydroacoustic estimates of fish densities in comparison with stratified pelagic trawl sampling in two deep, coregonid-dominated lakes. Fish. Res. 105: 178-186. doi:10.1016/j.fishres.2010.05.001.

Emmrich, M., Winfield, I.J., Guillard, J., Rustadbakken, A., Verges, C., Volta, P., Jeppesen, E., Lauridsen, T.L., Brucet, S., Holmgren, K., Argillier, C. and Mehner, T. 2012. Strong correspondence between gillnet catch per unit effort and hydroacoustically derived fish biomass in stratified lakes. Freshw. Biol. 57: 24362448. doi:10.1111/fwb.12022. 
649 Everson, I., Taabu-Munyaho, A. and Kayanda, R. 2013. Acoustic estimates of commercial

650 fish species in Lake Victoria: Moving towards ecosystem-based fisheries management. Fish. Res. 139: 65-75. doi:10.1016/j.fishres.2012.09.019.

Fabrizio, M.C., Adams, J. V. and Curtis, G.L. 1997. Assessing prey fish populations in Lake Michigan: comparison of simultaneous acoustic-midwater trawling with bottom trawling. Fish. Res. 33: 37-54. doi:10.1016/S0165-7836(97)00061-1.

Fleischer, G.W., Argyle, R.L. and Curtis, G.L. 1997. In situ relations of target strength to fish size for Great Lakes pelagic planktivores. Trans. Am. Fish. Soc. 126: 786-794. doi:10.1577/1548-8659(1997)126<0786:ISROTS>2.3.CO;2.

658

659

660

661

662

663

664

665

666

667

668
Fleischer, G.W. and Tewinkel, L.M. 1998. Buoyancy characteristics of the bloater (Coregonus hoyi) in relation to patterns of vertical migration and acoustic backscattering. Ergebnisse der Limnol. 50: 219-225.

Fraser, D.J., Weir, L.K., Bernatchez, L., Hansen, M.M. and Taylor, E.B. 2011. Extent and scale of local adaptation in salmonid fishes: review and meta-analysis. Heredity (Edinb). 106: 404-20. doi:10.1038/hdy.2010.167.

Frear, P.A. 2002. Hydroacoustic target strength validation using angling creel census data. Fish. Manag. Ecol. 9: 343-350. doi:10.1046/j.1365-2400.2002.00312.x.

Frouzova, J. and Kubecka, J. 2004. Changes of acoustic target strength during juvenile perch development. Fish. Res. 66: 355-361. doi:10.1016/S0165-7836(03)00182-6.

Frouzova, J., Kubecka, J., Balk, H., \& Frouz, J. 2005.. Target strength of some European 

fish species and its dependence on fish body parameters. Fish. Res., 75: 86-96. doi:10.1016/j.fishres.2005.04.011.

671 Gaudreau, N. and Boisclair, D. 1998. The influence of spatial heterogeneity on the study of fish horizontal daily migration. Fish. Res. 35: 65-73. doi:10.1016/S0165-

Gaudreau, N. and Boisclair, D. 2000. Influence of moon phase on acoustic estimates of the abundance of fish performing daily horizontal migration in a small oligotrophic lake. Can. J. Fish. Aquat. Sci. 57: 581-590. doi:10.1139/f99-277.

Gauthier, S., Boisclair, D. and Legendre, P. 1997. Evaluation of a variable angle scanning method to estimate relative abundance and distribution of fish using a single-beam echosounder in shallow lakes. J. Fish Biol. 50: 208-221. doi:10.1111/j.10958649.1997.tb01352.x.

George, D.G. and Winfield, I.J. 2000. Factors influencing the spatial distribution of

zooplankton and fish in Loch Ness, UK. Freshw. Biol. 43: 557-570.

doi:10.1046/j.1365-2427.2000.00539.x.

Getabu, A., Tumwebaze, R. and MacLennan, D.N. 2003. Spatial distribution and temporal changes in the fish populations of Lake Victoria. Aquat. Living Resour. 16: 159-165.

Gjelland, K. and Bohn, T. 2004. Influence of light on the swimming speed of coregonids in subarctic lakes. Ann. Zool. Fennici 41: 137-146. 
689 Godlewska, M. 2003. Hydroacoustical parameters of fish in reservoirs with contrasting 690 levels of eutrophication. Aquat. Living Resour. 16: 167-173. doi:10.1016/S09907440(03)00014-7.

692 Godlewska, M., Colon, M., Doroszczyk, L., Długoszewski, B., Verges, C. and Guillard, J. 693 2009a. Hydroacoustic measurements at two frequencies: 70 and $120 \mathrm{kHz}-$ 694 consequences for fish stock estimation. Fish. Res. 96: 11-16. 695 doi:10.1016/j.fishres.2008.09.015.

696 Godlewska, M., Długoszewski, B., Doroszczyk, L. and Jóźwik, A. 2009b. The relationship 697 between sampling intensity and sampling error-empirical results from acoustic surveys in Polish vendace lakes. Fish. Res. 96: 17-22. doi:

Godlewska, M., Izydorczyk, K., Kaczkowski, Z., Jóźwik, A., Długoszewski, B., Ye, S., 10.1016/j.fishres.2008.09.014. Lian, Y. and Guillard, J. 2015. Do fish and blue-green algae blooms coexist in space and time? Fish. Res. 173: 93-100. doi:10.1016/j.fishres.2015.06.018.

Goldspink, C.R. 1990. The distribution and abundance of young (I+-II +) perch, Perca fluviatilis L., in a deep eutrophic lake, England. J. Fish Biol. 36: 439-447.

Goudswaard, K. P. C.., Wanink, J.H., Witte, F., Katunzi, E.F.B., Berger, M.R. and Postma, D.J. 2004. Diel vertical migration of major fish-species in Lake Victoria, East Africa. HydroBiologia (Bratisl). 513: 141-152. doi:10.1023/B:hydr.0000018179.80116.93. 
709 Guillard, J., Balay, P., Colon, M. and Brehmer, P. 2010. Survey boat effect on YOY fish

710 schools in a pre-alpine lake: evidence from multibeam sonar and split-beam

711 echosounder data. Ecol. Freshw. Fish 19: 373-380. doi:10.1111/j.1600-

$712 \quad$ 0633.2010.00419.x.

713 Guillard, J., Boet, P., Gerdeaux, D. and Roux, P. 1994. Application of mobile acoustic

714 techniques fish surveys in shallow water: The river seine. Regul. Rivers Res. Manag.

715 9: 121-126. doi:10.1002/rrr.3450090205.

716 Guillard, J. and Colon, M. 2000. First results on migrating shad (Alosa fallax) and mullet

717 (Mugil cephalus) echocounting in a lock on the Rhône River (France) using a split-

718 beam sounder, and relationships with environmental data and fish caught. Aquat.

719 Living Resour. 13: 327-330. doi:10.1016/S0990-7440(00)01058-5.

720 Guillard, J., Darchambeau, F., Mulungula, P.M. and Descy, J.-P. 2012. Is the fishery of the

721 introduced Tanganyika sardine (Limnothrissa miodon) in Lake Kivu (East Africa)

722 sustainable? J. Great Lakes Res. 38: 524-533. doi:10.1016/j.jglr.2012.05.004.

723 Guillard, J. and Gerdeaux, D. 1993. In situ determination of the target strength of roach

724 (Rutilus rutilus) in lake Bourget with a single beam sounder. Aquat. Living Resour. 6:

725 285-289. doi:10.1051/alr:1993028.

726 Guillard, J., Lebourges-Dhaussy, A. and Brehmer, P. 2004. Simultaneous Sv and TS

727 measurements on Young-of-the-Year (YOY) freshwater fish using three frequencies.

728 ICES J. Mar. Sci. 61: 267-273. doi:10.1016/j.icesjms.2003.11.007. 
729 Guillard, J., Perga, M.E., Colon, M. and Angeli, N. 2006a. Hydroacoustic assessment of 730 young-of-year perch, Perca fluviatilis, population dynamics in an oligotrophic lake

731 (Lake Annecy, France). Fish. Manag. Ecol. 13: 319-327. doi:10.1111/j.13652400.2006.00508.x.

733 Guillard, J. and Vergès, C. 2007. The repeatability of fish biomass and size distribution

734 estimates obtained by hydroacoustic surveys using various sampling strategies and statistical analyses. Int. Rev. Hydrobiol. 92: 605-617. doi:10.1002/iroh.200710948.

736

737

738

739

740

741

742

743

744

745

746

747

Haga, H., Ohtsuka, T., Matsuda, M. and Ashiya, M. 2007. Echosounding observations of coverage, height, PVI, and biomass of submerged macrophytes in the southern basin of Lake Biwa, Japan. Limnology 8: 95-102. doi:10.1007/s10201-006-0200-2.

Hampton, I. 1987. Acoustic study on the abundance and distribution of anchovy spawners and recruits in South African waters. South African J. Mar. Sci. 5: 901-917. doi:10.2989/025776187784522450.

Hamrin, S.F. 1986. Vertical distribution and habitat partitioning between different size classes of Vendace, Coregonus albula, in thermally stratified lakes. Can. J. Fish. Aquat. Sci. 43: 1617-1625. doi:10.1139/f86-200.

Haralabous, J. and Georgakarakos, S. 1996. Artificial neural networks as a tool for species identification of fish schools. ICES J. Mar. Sci. 53: 173-180. doi:10.1006/jmsc.1996.0019.

Harrison, A.J., Kelly, F.L., Rosell, R.S., Champ, T.W.S., Connor, L. and Girvan, J.R. 2010. 
First record and initial hydroacoustic stock assessment of pollan Coregonus autumnalis Pallas in Lough Allen, Ireland. Biol. Environ. Proc. R. Irish Acad. 110: 69-74. doi:10.3318/BIOE.2010.110.1.69.

752

753

Hartman, K. J., \& Nagy, B. W. 2005. A target strength and length relationship for striped bass and white perch. Trans. Am. Fish. Soc. 134: 375-380. doi:10.1577/T04-052.1

Hasler, A.D. and Villemonte, J.R. 1953. Observations on the daily movements of fishes. Science 118: 321-322. doi:10.1126/science.118.3064.321.

Heist, B.G. and Swenson, W.A. 1983. Distribution and abundance of rainbow smelt in Western Lake Superior as determined from acoustic sampling. J. Great Lakes Res. 9: 343-353. doi:10.1016/S0380-1330(83)71905-2.

Hergenrader, G.L. and Hasler, A.D. 1967. Seasonal changes in swimming rates of yellow perch in Lake Mendota as measured by sonar. Trans. Am. Fish. Soc. 96: 373-382. doi:10.1577/1548-8659(1967)96[373:SCISRO]2.0.CO;2.

Holbrook, B. V., Hrabik, T.R., Branstrator, D.K., Yule, D.L. and Stockwell, J.D. 2006. Hydroacoustic estimation of zooplankton biomass at two shoal complexes in the Apostle Islands region of Lake Superior. J. Great Lakes Res. 32: 680-696. doi:10.3394/0380-1330(2006)32[680:HEOZBA]2.0.CO;2.

Horne, J.K. 2000. Acoustic approaches to remote species identification: a review. Fish. Oceanogr. 9: 356-371. doi:10.1046/j.1365-2419.2000.00143.x.

Horne, J.K., Walline, P.D. and Jech, J.M. 2000. Comparing acoustic model predictions to 
in situ backscatter measurements of fish with dual-chambered swimbladders. J. Fish Biol. 57: 1105-1121. doi:10.1111/j.1095-8649.2000.tb00474.x.

Horppila, J., Malinen, T. and Peltonen, H. 1996. Density and habitat shifts of a roach (Rutilus rutilus) stock assessed within one season by cohort analysis, depletion methods and echosounding. Fish. Res. 28: 151-161. doi:10.1016/01657836(96)00499-7.

Hrabik, T.R., Jensen, O.P., Martell, S.J.D., Walters, C.J. and Kitchell, J.F. 2006. Diel vertical migration in the Lake Superior pelagic community. I. Changes in vertical migration of coregonids in response to varying predation risk. Can. J. Fish. Aquat. Sci. 63: 2286-2295. doi:10.1139/f06-124.

HTI, Inc. 2015. How do hydroacoustics work? [Online]. Available from http://www.htisonar.com/what_are_hydroacoustics.htm [Accessed 03 May 2016].

Hughes, J.B. and Hightower, J.E. 2015. Combining split-beam and dual-Frequency identification sonars to estimate abundance of anadromous fishes in the Roanoke River, North Carolina. North Am. J. Fish. Manag. 35: 229-240. doi:10.1080/02755947.2014.992558.

Hughes, S. 1998. A mobile horizontal hydroacoustic fisheries survey of the River Thames, United Kingdom. Fish. Res. 35: 91-97. doi:10.1016/S0165-7836(98)00063-0.

Iida, K. and Mukai, T. 1995. Behavior of kokanee Oncorhynchus nerka in Lake Kuttara observed by echo sounder. Fish. Sci. 61: 641-646. doi:10.2331/fishsci.61.641. 
789 Imbrock, F., Appenzeller, A., and Eckmann, R. 1996. Diel and seasonal distribution of 790 perch in Lake Constance: a hydroacoustic study and in situ observations. J. Fish Biol. 49: 1-13. doi:10.1111/j.1095-8649.1996.tb00001.x.

\section{2}

793

794

795

796

797

Jackson, D.A., Peres-Neto, P.R. and Olden, J.D. 2001. What controls who is where in freshwater fish communities - the roles of biotic, abiotic, and spatial factors. Can. J. Fish. Aquat. Sci. 58: 157-170. doi:10.1139/f00-239.

Janssen, J. and Brandt, S.B. 1980. Feeding ecology and vertical migration of adult alewives ( Alosa pseudoharengus ) in Lake Michigan. Can. J. Fish. Aquat. Sci. 37: 177-184. doi:10.1139/f80-023.

Jensen, O.P., Hrabik, T.R., Martell, S.J.D., Walters, C.J. and Kitchell, J.F. 2006. Diel vertical migration in the Lake Superior pelagic community. II. Modeling trade-offs at an intermediate trophic level. Can. J. Fish. Aquat. Sci. 63: 2296-2307. doi:10.1139/f06-125.

Jeppesen, E., Mehner, T., Winfield, I.J., Kangur, K., Sarvala, J., Gerdeaux, D., Rask, M., Malmquist, H.J., Holmgren, K., Volta, P., Romo, S., Eckmann, R., Sandström, A., Blanco, S., Kangur, A., Ragnarsson Stabo, H., Tarvainen, M., Ventelä, A.-M., Søndergaard, M., Lauridsen, T.L. and Meerhoff, M. 2012. Impacts of climate warming on the long-term dynamics of key fish species in 24 European lakes. HydroBiologia (Bratis1). 694: 1-39. doi:10.1007/s10750-012-1182-1.

Johannesson, K.A. and Mitson, R.B. 1983. Fisheries acoustics: A practical manual for 

aquatic biomass estimation. Rome, Italy: Food and Agricultural Organization of the $810 \quad$ United Nations (FAO). 249 p.

811 Johnson, B.M. and Goettl, J.P. 1999. Food web changes over fourteen years following 812 introduction of rainbow smelt into a Colorado Reservoir. North Am. J. Fish. Manag. 813 19: 629-642. doi:10.1577/1548-8675(1999)019<0629:FWCOFY>2.0.CO;2.

814 Johnson, G.E., Sullivan, C.M. and Erho, M.W. 1992. Hydroacoustic studies for developing 815 a smolt bypass system at Wells Dam. Fish. Res. 14: 221-237. doi:10.1016/0165$816 \quad 7836(92) 90055-X$

817 Johnson, R. 2000. Evaluation of juvenile salmon behavior at Bonneville Dam, Columbia 818 River, using a multibeam technique. Aquat. Living Resour. 13: 313-318. 819 doi:10.1016/S0990-7440(00)01088-3.

820 Jones, I.D., Winfield, I.J. and Carse, F. 2008. Assessment of long-term changes in habitat 821 availability for Arctic charr (Salvelinus alpinus) in a temperate lake using oxygen 822 profiles and hydroacoustic surveys. Freshw. Biol. 53: 393-402. doi:10.1111/j.1365$823 \quad$ 2427.2007.01902.x.

824 Jurvelius, J., Kolari, I. and Leskelä, A. 2010. Quality and status of fish stocks in lakes:

825 gillnetting, seining, trawling and hydroacoustics as sampling methods. HydroBiologia

826 (Bratisl). 660: 29-36. doi:10.1007/s10750-010-0385-6.

827 Jurvelius, J., Lindem, T. and Louhimo, J. 1984. The number of pelagic fish in Lake

828 Paasivesi, Finland, monitored by hydroacoustic methods. Fish. Res. 2: 273-283. 
doi:10.1016/0165-7836(84)90030-4.

Jurvelius, J. and Marjomaki, T.J. 2004. Vertical distribution and swimming speed of pelagic fishes in winter and summer monitored in situ by acoustic target tracking. Boreal Environ. Res. 9: 277-284. doi:10.1111/j.0022-1112.2004.00307.x.

Jurvelius, J. and Marjomaki, T.J. 2008. Night, day, sunrise, sunset: do fish under snow and ice recognize the difference? Freshw. Biol. 53: 2287-2294. doi:10.1111/j.13652427.2008.02055.x.

Jurvelius, J. and Sammalkorpi, I. 1995. Hydroacoustic monitoring of the distribution, density and the mass-removal of pelagic fish in a eutrophic lake. HydroBiologia (Bratisl). 316: 33-41. doi:10.1007/BF00019373.

Kahilainen, K., Malinen, T., Tuomaala, A. and Lehtonen, H. 2004. Diel and seasonal habitat and food segregation of three sympatric Coregonus lavaretus forms in a subarctic lake. J. Fish Biol. 64: 418-434. doi:10.1111/j.0022-1112.2004.00307.x.

Kalikhman, I., Walline, P. and Gophen, M. 1992. Simultaneous patterns of temperature, oxygen, zooplankton and fish distribution in Lake Kinneret, Israel. Freshw. Biol. 28: 337-347. doi:10.1111/j.1365-2427.1992.tb00592.x.

Kalikhman, I.L. and Yudanov, K.I. 2006. Acoustic Fish Reconnaissance. Boca Raton, Florida, United States: CRC Press/Taylor and Francis Group. 272 p.

Kang, M., Furusawa, M. and Miyashita, K. 2002. Effective and accurate use of difference in mean volume backscattering strength to identify fish and plankton. ICES J. Mar. 
Sci. 59: 794-804. doi:10.1006/jmsc.2002.1229.

Kayanda, R., Everson, I., Munyaho, T. and Mgaya, Y. 2012. Target strength measurements of Nile perch (Lates niloticus: Linnaeus, 1758). in Lake Victoria, East Africa. Fish. Res. 113: 76-83. doi:10.1016/j.fishres.2011.10.003.

Kelso, J.R.M. and Minns, C.K. 1975. Summer distribution of the nearshore fish community near a thermal generating station as determined by acoustic census. J. Fish. Res. Board Canada 32, 1409-1418. doi:10.1139/f75-160.

de Kerckhove, D.T., Shuter, B.J. and Milne, S. 2016. Acoustically derived fish size-spectra within a lake and the statistical power to detect environmental change. Can. J. Fish. Aquat. Sci. 73: 565-574. doi:10.1139/cjfas-2015-0222.

Knudsen, F.R. and Gjelland, K.Ø. 2004. Hydroacoustic observations indicating swimbladder volume compensation during the diel vertical migration in coregonids (Coregonus lavaretus and Coregonus albula). Fish. Res. 66: 337-341. doi:10.1016/S0165-7836(03)00191-7.

Knudsen, F.R. and Larsson, P. 2009. Discriminating the diel vertical migration of fish and Chaoborus flavicans larvae in a lake using a dual-frequency echo sounder. Aquat. Living Resour. 22: 273-280. doi:10.1051/alr/2009029.

Knudsen, F.R., Larsson, P. and Jakobsen, P.J. 2006. Acoustic scattering from a larval insect (Chaoborus flavicans) at six echosounder frequencies: Implication for acoustic estimates of fish abundance. Fish. Res. 79: 84-89. doi:10.1016/j.fishres.2005.11.024. 
869

870

871

872

873

874

875

876

Knudsen, F.R. and Sægrov, H. 2002. Benefits from horizontal beaming during acoustic survey: application to three Norwegian lakes. Fish. Res. 56: 205-211. doi:10.1016/S0165-7836(01)00318-6.

Koslow, J.A. 2009. The role of acoustics in ecosystem-based fishery management. ICES J. Mar. Sci. 66: 966-973. doi:10.1093/icesjms/fsp082.

Kubečka, J. 1994. Simple model on the relationship between fish acoustical target strength and aspect for high-frequency sonar in shallow waters. J. Appl. Ichthyol. 10: 75-81. doi:10.1111/j.1439-0426.1994.tb00146.x.

Kubecka, J. and Duncan, A. 1998a. Acoustic size vs. real size relationships for common species of riverine fish. Fish. Res. 35: 115-125. doi:10.1016/S0165-7836(98)00066-6.

Kubecka, J. and Duncan, A. 1998b. Diurnal changes of fish behaviour in a lowland river monitored by a dual-beam echosounder. Fish. Res. 35: 55-63. doi:10.1016/S01657836(98)00059-9.

Kubecka, J., Duncan, A., Duncan, W.M., Sinclair, D. and Butterworth, A.J. 1994. Brown trout populations of three Scottish lochs estimated by horizontal sonar and multimesh gill nets. Fish. Res. 20: 29-48. doi:10.1016/0165-7836(94)90004-3.

Kubečka, J., Hohausová, E., Matěna, J., Peterka, J., Amarasinghe, U.S., Bonar, S.A., Hateley, J., Hickley, P., Suuronen, P., Tereschenko, V., Welcomme, R. and Winfield, I.J. 2009. The true picture of a lake or reservoir fish stock: A review of needs and progress. Fish. Res. 96: 1-5. doi:10.1016/j.fishres.2008.09.021. 
889 Kubecka, J. and Svatora, M. 1993. Abundance estimates of perch fry (Perca fluviatilis), 890 complicated by grouped behaviour. Ecol. Freshw. Fish 2: 84-90. doi:10.1111/j.16000633.1993.tb00087.x.

892 Kubecka, J. and Wittingerova, M. 1998. Horizontal beaming as a crucial component of 893 acoustic fish stock assessment in freshwater reservoirs. Fish. Res. 35: 99-106. doi:10.1016/S0165-7836(98)00064-2.

Langkau, M.C., Balk, H., Schmidt, M.B. and Borcherding, J. 2012. Can acoustic shadows identify fish species? A novel application of imaging sonar data. Fish. Manag. Ecol. 19: 313-322. doi:10.1111/j.1365-2400.2011.00843.x.

Latour, R.J., Brush, M.J. and Bonzek, C.F. 2003. Toward ecosystem-based fisheries management. Fisheries 28: 10-22. doi: 10.1577/1548-

Lawson, G., Barange, M. and Freon, P. 2001. Species identification of pelagic fish schools 8446(2003)28[10:TEFM]2.0.CO;2.

Leggett, W.C. and Carscadden, J.E. 1978. Latitudinal variation in reproductive characteristics of American Shad (Alosa sapidissima): Evidence for population specific life history strategies in fish. J. Fish. Res. Board Canada 35: 1469-1478. doi:10.1139/f78-230. 
diversity of fish (Pisces) in freshwater. Dev. Hydrobiol. 595: 545-567.

910 doi:10.1007/978-1-4020-8259-7.

911

Lilja, J., Marjomaki, T.J., Riikonen, R. and Jurvelius, J. 2000. Side-aspect target strength of

912 Atlantic salmon (Salmo salar), brown trout (Salmo trutta), whitefish (Coregonus

913 lavaretus), and pike (Esox lucius). Aquat. Living Resour. 13: 355-360.

914 doi:10.1016/S0990-7440(00)01072-X.

915 Lin, P.-C., Brosse, S., Gao, X., Liu, C.-C. and Liu, H.-Z. 2013a. Species composition and

916 temporal pattern of fish passing through the navigation locks in the middle reach of

917 Yangtze River: implications for fish conservation. J. Appl. Ichthyol. 29: 1441-1444.

918 doi:10.1111/jai.12362.

919 Lin, P.-C., Gao, X., Zhu, Q.-G., Wang, T. and Liu, H.-Z. 2013b. Hydroacoustic survey on

920 the spatial distribution pattern and day-night rhythmic behaviour of fishes in the

921 Xiaonanhai reach of the upper Yangtze River. J. Appl. Ichthyol. 29: 1402-1407.

922 doi:10.1111/jai.12342.

923 Linløkken, A. 1995. Monitoring pelagic whitefish (Coregonus lavaretus) and vendace

924 (Coregonus albula) in a hydroelectric reservoir using hydroacoustics. Regul. Rivers

925 Res. Manag. 10: 315-328. doi:10.1002/rrr.3450100224.

926 Loures, R.C. and Pompeu, P.S. 2015. Seasonal and diel changes in fish distribution in a

927 tropical hydropower plant tailrace: evidence from hydroacoustic and gillnet sampling.

928 Fish. Manag. Ecol. 22: 185-196. doi:10.1111/fme.12116. 
929 Lu, H.. and Lee, K.. 1995. Species identification of fish shoals from echograms by an echo-

$930 \quad$ signal image processing system. Fish. Res. 24: 99-111. doi:10.1016/0165-

$931 \quad 7836(94) 00368-7$.

932 Lynch, A.J., Cooke, S.J., Deines, A.M., Bower, S.D., Bunnell, D.B., Cowx, I.G., Nguyen,

933 V.M., Nohner, J., Phouthavong, K., Riley, B., Rogers, M.W., Taylor, W.W., Woelmer,

934 W., Youn, S.-J. and Beard, T.D. 2016. The social, economic, and environmental

935 importance of inland fish and fisheries. Environ. Rev. doi: 10.1139/er-2015-0064.

936 Lyons, J. 1998. A hydroacoustic assessment of fish stocks in the River Trent, England.

937 Fish. Res. 35: 83-90. doi:10.1016/S0165-7836(98)00062-9.

938 MacLennan, D.N. 1992. Fishing gear selectivity: an overview. Fish. Res. 13: 201-204. doi:

$939 \quad 10.1016 / 0165-7836(92) 90076-6$.

940 Malinen, T. and Tuomaala, A. 2005. Comparison of day and night surveys in hydro-

941 acoustic assessment of smelt (Osmerus eperlanus) density in Lake Hiidenvesi. Adv.

$942 \quad$ Limnol. 59: 161-172.

943 Marjomäki, T. and Huolila, M. 1995. Monitoring the density of Lake Puulavesi vendace

944 (Coregonus albula (L.)) by hydroacoustics, catch per unit effort, virtual population

945 and catch per swept. Adv. Limnol. 46: 267-276.

946 Marjomaki, T.J. and Huolila, M. 2001. Long-term dynamics of pelagic fish density and

947 vendace (Coregonus albula (L.)) stocks in four zones of a lake differing in trawling

948 intensity. Ecol. Freshw. Fish 10: 65-74. doi:10.1034/j.1600-0633.2001.100201.x. 
949 Martignac, F., Daroux, A., Bagliniere, J.-L., Ombredane, D. and Guillard, J. 2014. The use 950 of acoustic cameras in shallow waters: new hydroacoustic tools for monitoring migratory fish population. A review of DIDSON technology. Fish Fish. 16: 486-510.

Mason, D.M., Johnson, T.B., Harvey, C.J., Kitchell, J.F., Schram, S.T., Bronte, C.R., Hoff, M.H., Lozano, S.J., Trebitz, A.S., Schreiner, D.R., Conrad Lamon, E. and Hrabik, T. 2005. Hydroacoustic estimates of abundance and spatial distribution of pelagic prey

Masson, S., Angeli, N., Guillard, J. and Pinel-Alloul, B. 2001. Diel vertical and horizontal

962

963

964

965

966

967

968 doi:10.1111/faf.12071. fishes in Western Lake Superior. J. Great Lakes Res. 31: 426-438. doi:10.1016/S0380-1330(05)70274-4. distribution of crustacean zooplankton and young of the year fish in a sub-alpine lake: an approach based on high frequency sampling. J. Plankton Res. 23: 1041-1060. doi:10.1093/plankt/23.10.1041.

Matveev, V. 2003. Testing predictions of the lake food web theory on pelagic communities of Australian reservoirs. Oikos 100: 149-161. doi:10.1034/j.1600-0706.2003.11651.x.

Matveev, V.F. 2007. Assessing the biomass of small fish with a split-beam sonar in the Murray River, Australia. Fish. Res. 88: 139-145. doi:10.1016/j.fishres.2007.07.008.

McClatchie, S., Alsop, J., and Coombs, R. F. 1996. A re-evaluation of relationships between fish size, acoustic frequency, and target strength. ICES J. Mar. Sci. 53: 780791. doi:10.1006/jmsc.1996.0099. 
969 Mehner, T. 2006a. Individual variability of diel vertical migrations in European vendace

$970 \quad$ (Coregonus albula) explored by stationary vertical hydroacoustics. Ecol. Freshw. Fish

971 15: 146-153. doi:10.1111/j.1600-0633.2006.00137.x.

972 Mehner, T. 2006b. Prediction of hydroacoustic target strength of vendace (Coregonus

973 albula) from concurrent trawl catches. Fish. Res. 79: 162-169.

974 doi:10.1016/j.fishres.2006.01.014.

975 Mehner, T., Busch, S., Helland, I.P., Emmrich, M. and Freyhof, J. 2010. Temperature-

$976 \quad$ related nocturnal vertical segregation of coexisting coregonids. Ecol. Freshw. Fish 19:

977 408-419. doi:10.1111/j.1600-0633.2010.00424.x.

978 Mehner, T., Gassner, H., Schulz, M. and Wanzenbock, J. 2003. Comparative fish stock

979 estimates in Lake Stechlin by parallel split-beam echosounding with $120 \mathrm{kHz}$. Adv.

$980 \quad$ Limnol. 58: 227-236.

981 Mehner, T., Hölker, F. and Kasprzak, P. 2005. Spatial and temporal heterogeneity of

982 trophic variables in a deep lake as reflected by repeated singular samplings. Oikos

983 108: 401-409. doi:10.1111/j.0030-1299.2005.13338.x.

984 Mehner, T., Kasprzak, P. and Hölker, F. 2007. Exploring ultimate hypotheses to predict

985 diel vertical migrations in coregonid fish. Can. J. Fish. Aquat. Sci. 64: 874-886.

986 doi:10.1139/f07-067.

987 Mehner, T. and Schulz, M. 2002. Monthly variability of hydroacoustic fish stock estimates

988 in a deep lake and its correlation to gillnet catches. J. Fish Biol. 61: 1109-1121. 
doi:10.1111/j.1095-8649.2002.tb02459.x.

990

991

992

993

994

995

996

997

998

999

1000

1001

1002

1003

1004

1005

1006

1007

1008

Mochek, A.D., Borisenko, E.S., Budaev, S. V. and Pavlov, D.S. 2015. Summer and autumn distribution of fish in Lake Glubokoe. J. Ichthyol. 55: 355-362. doi:10.1134/S003294521503008X.

Mueller, A.-M., Burwen, D.L., Boswell, K.M. and Mulligan, T. 2010. Tail-beat patterns in dual-frequency identification sonar echograms and their potential use for species identification and bioenergetics studies. Trans. Am. Fish. Soc. 139: 900-910. doi:10.1577/T09-089.1.

Mukai, T. and Iida, K. 1996. Depth dependence of target strength of live kokanee salmon in accordance with Boyle's law. ICES J. Mar. Sci. 53: 245-248. doi:10.1006/jmsc.1996.0029.

Nealson, P. and Gregory, J. 2000. Hydroacoustic differentiation of adult Atlantic salmon and aquatic macrophytes in the River Wye, Wales. Aquat. Living Resour. 13: 331339. doi:10.1016/S0990-7440(00)01093-7.

Nyberg, P., Bergstrand, E., Degerman, E. and Enderlein, O. 2001. Recruitment of pelagic fish in an unstable climate: Studies in Sweden's four largest lakes. AMBIO A J. Hum. Environ. 30: 559-564. doi:10.1579/0044-7447-30.8.559.

Ogari, J. and Dadzie, S. 1988. The food of the Nile perch, Lates niloticus (L.), after the disappearance of the haplochromine cichlids in the Nyanza Gulf of Lake Victoria (Kenya). J. Fish Biol. 32: 571-577. doi:10.1111/j.1095-8649.1988.tb05396.x. 
1009 Okamoto, M., Okumoto, N., Iwata, M., Ikuta, K. and Fukusho, K. 1993. Vertical

1010 distribution of Salmonidae mainly consisting of Hime salmon Oncorhynchus nerka in 1011 Chuzenji Lake. Bull. Japanese Soc. Sci. Fish. 59: 1813-1821.

1012 Oldani, N.O. and Baigun, C.R.M. 2002. Performance of a fishway system in a major South 1013 American dam on the Parana River (Argentina-Paraguay). River Res. Appl. 18: 1711014 183. doi:10.1002/rra.640.

1015 Ona, E. 1990. Physiological factors causing natural variations in acoustic target strength of 1016 fish. J. Mar. Biol. Assoc. United Kingdom 70: 107-127.

1017 doi:10.1017/S002531540003424X.

1018 Pauly, D. 1995. Anecdotes and the shifting baseline syndrome of fisheries. Trends Ecol.

$1019 \quad$ Evol., 10: 430. doi:10.1016/S0169-5347(00)89171-5.

1020 Pavlov, D.S., Gusar, A.G., Pyanov, A.I. and Gorin, A.N. 1986. The results of hydroacoustic 1021 observations on roach in Lake Glubokoe in winter. HydroBiologia (Bratisl). 141: 1251022 132. doi:10.1007/BF00007485.

1023 Peirson, G. and Frear, P.A. 2003. Fixed location hydroacoustic monitoring of fish 1024 populations in the tidal River Hull, north-east England, in relation to water quality. 1025 Fish. Manag. Ecol. 10: 1-12. doi:10.1046/j.1365-2400.2003.00316.x.

1026 Peterson, M.L., Clay, C.S. and Brandt, S.B. 1976. Acoustic estimates of fish density and 1027 scattering function. J. Acoust. Soc. Am. 60: 618-622. doi:10.1121/1.381123.

1028 Pieper, R.E. and Holliday, D. V. 1984. Acoustic measurements of zooplankton distributions 

in the sea. ICES J. Mar. Sci. 41: 226-238. doi: 10.1093/icesjms/41.3.226.

1030

1031

1032

1033

1034

1035

1036

1037

1038

1039

1040

1041

1042

1043

1044

1045

1046

1047

1048

Pollom, R.A. and Rose, G.A. 2015. Size-based hydroacoustic measures of within-season fish abundance in a boreal freshwater ecosystem. PLoS One 10: e0124799. doi:10.1371/journal.pone.0124799.

Prchalova, M., Drastik, V., Kubecka, J., Sricharoendham, B., Schiemer, F. and Vijverberg, J. 2003. Acoustic study of fish and invertebrate behavior in a tropical reservoir. Aquat. Living Resour. 16: 325-331. doi:10.1016/S0990-7440(03)00047-0.

Prchalová, M., Kubečka, J., Čech, M., Frouzová, J., Draštík, V., Hohausová, E., Jůza, T., Kratochvíl, M., Matěna, J., Peterka, J., Říha, M., Tušer, M. and Vašek, M. 2009. The effect of depth, distance from dam and habitat on spatial distribution of fish in an artificial reservoir. Ecol. Freshw. Fish 18: 247-260. doi:10.1016/S09907440(03)00047-0.

Probst, W.N. and Eckmann, R. 2009. The influence of light on the diel vertical migration of young-of-the-year burbot Lota lota in Lake Constance. J. Fish Biol. 74: 150-66. doi:10.1111/j.1095-8649.2008.02120.x.

Ptak, J. and Appenzeller, A. 1998. Size, depth, and frequency of pelagic Lake Constance whitefish (Coregonus lavaretus L.) shoals during the seasons: a hydroacoustic study. Ergebnisse der Limnol. 50: 237-248.

Qiao, Y., Tang, X., Brosse, S. and Chang, J. 2006. Chinese Sturgeon (Acipenser sinensis) in the Yangtze River: a hydroacoustic assessment of fish location and abundance on 
1049 the last spawning ground. J. Appl. Ichthyol. 22: 140-144. doi:10.1111/j.1439$1050 \quad$ 0426.2007.00942.x.

1051 Ransom, B.H., Johnston, S. V and Steig, T.W. 1998. Review on monitoring adult salmonid 1052 (Oncorhynchus and Salmo spp.) escapement using fixed-location split-beam 1053 hydroacoustics. Fish. Res. 35: 33-42. doi:10.1016/S0165-7836(98)00057-5.

1054 Robotham, H., Bosch, P., Gutiérrez-Estrada, J.C., Castillo, J. and Pulido-Calvo, I. 2010.

1055 Acoustic identification of small pelagic fish species in Chile using support vector 1056 machines and neural networks. Fish. Res. 102: 115-122.

1057 doi:10.1016/j.fishres.2009.10.015.

1058 Rodríguez-Sánchez, V., Encina-Encina, L., Rodríguez-Ruiz, A. and Sánchez-Carmona, R. 1059 2015. Do close range measurements affect the target strength (TS) of fish in horizontal 1060 beaming hydroacoustics? Fish. Res. 173: 4-10. doi:10.1016/j.fishres.2015.03.020.

1061 Romakkaniemi, A., Lilja, J., Nykänen, M., Marjomäki, T.J. and Jurvelius, J. 2000.

1062 Spawning run of Atlantic Salmon (Salmo salar) in the River Tornionjoki monitored by 1063 horizontal split-beam echosounding. Aquat. Living Resour. 13: 349-354. doi:

$1064 \quad 10.1016 / \mathrm{S} 0990-7440(00) 01083-4$.

1065 Romare, P. 2001. An evaluation of horizontal echo sounding as a method for behavioural

1066 studies of 0+ fish in field experiments. J. Fish Biol. 58: 1512-1523.

1067 doi:10.1111/j.1095-8649.2001.tb02308.x.

1068 Rose, G.A. 1992. A review of problems and new directions in the application of fisheries 
1069

1070

1071

1072

1073

1074

1075

1076

1077

1078

1079

1080

1081

1082

1083

1084

1085

1086

1087

1088

acoustics on the Canadian East Coast. Fish. Res. 14: 105-128. doi:10.1111/j.10958649.2001.tb02308.x.

Rose, G.A. and Leggett, W.C. 1988. Hydroacoustic signal classification of fish schools by species. Can. J. Fish. Aquat. Sci. 45: 597-604. doi:10.1139/f88-073.

Rosell, R.S. 1997. The status of pollan Coregonus autumnalis pollan Thompson in Lough Erne, Northern Ireland. Proc. R. Irish Acad. 97B: 163-171.

Ross, Q.E., Dunning, D.J., Thorne, R., Menezes, J.K., Tiller, G.W. and Watson, J.K. 1993. Response of alewives to high-frequency sound at a power plant intake on Lake Ontario. North Am. J. Fish. Manag. 13: 291-303. doi:10.1577/15488675(1993)013<0291:ROATHF>2.3.CO;2.

Rowe, D.K. 1994. Vertical segregation and seasonal changes in fish depth distributions between lakes of contrasting trophic status. J. Fish Biol. 45: 787-800. doi:10.1111/j.1095-8649.1994.tb00944.x.

Rowe, D.K. and Chisnall, B.L. 1995. Effects of oxygen, temperature and light gradients on the vertical distribution of rainbow trout, Oncorhynchus mykiss, in two North Island, New Zealand, lakes differing in trophic status. New Zealand Journal of Marine and Freshwater Research 29: 421-434. doi:10.1080/00288330.1995.9516676.

Rudstam, L.G., Clay, C.S. and Magnuson, J.J. 1987. Density and size estimates of Cisco (Coregonus artedii) using analysis of echo peak PDF from a single-transducer sonar. Can. J. Fish. Aquat. Sci. 44: 811-821. doi:10.1139/f87-099. 
1089 Rudstam, L.G., Hansson, S., Lindem, T. and Einhouse, D.W. 1999. Comparison of target

1090 strength distributions and fish densities obtained with split and single beam echo

$1091 \quad$ sounders. Fish. Res. 42: 207-214. doi:10.1016/S0165-7836(99)00047-8.

1092 Rudstam, L.G., Parker, S.L., Einhouse, D.W., Witzel, L.D., Warner, D.M., Stritzel, J.I.,

1093 Parrish, D.I. and Sullivan, P.J. 2003. Application of in situ target-strength estimations

1094 in lakes: examples from rainbow-smelt surveys in Lakes Erie and Champlain. ICES J.

1095 Mar. Sci. 60: 500-507. doi:10.1016/S1054-3139(03)00046-8.

1096 Rudstam, L.G., Parker-Stetter, S.L., Sullivan, P.J. and Warner, D.M. 2009. Towards a

1097 standard operating procedure for fishery acoustic surveys in the Laurentian Great

1098 Lakes, North America. ICES J. Mar. Sci. 66: 1391-1397. doi:10.1093/icesjms/fsp014.

1099 Rudstam, L.G., VanDeValk, A.J. and Scheuerell, M.D. 2002. Comparison of acoustic and

1100 Miller high-speed sampler estimates of larval fish abundance in Oneida Lake, New

$1101 \quad$ York. Fish. Res. 57: 145-154. doi:10.1016/S0165-7836(01)00347-2.

1102 Scalabrin, C., Diner, N., Weill, A. and Mouchot, M.-C. 1996. Narrowband acoustic

1103 identification of monospecific fish shoals. ICES J. Mar. Sci. 53: 181-188.

1104 doi:10.1006/jmsc.1996.0020.

1105 Schmidt, M.B. 2009. Reactions of vendace (Coregonus albula, Linnaeus 1758. towards an

1106 approaching pelagic pair-trawl observed by split-beam echosounding. Fish. Res. 96:

1107 95-101. doi:10.1016/j.fishres.2008.09.006.

1108 Schmidt, M.B. and Gassner, H. 2006. Influence of scuba divers on the avoidance reaction 
1109 of a dense vendace (Coregonus albula L.) population monitored by hydroacoustics.

$1110 \quad$ Fish. Res. 82: 131-139. doi:10.1016/j.fishres.2006.08.014.

1111 Schmidt, M.B., Gassner, H. and Meyer, E.I. 2005. Distribution and biomass of an

1112 underfished vendace, Coregonus albula, population in a mesotrophic German

1113 reservoir. Fish. Manag. Ecol. 12: 169-175. doi:10.1111/j.1365-2400.2005.00439.x.

1114 Simmonds, J. and MacLennan, D. 2005. Fisheries Acoustics: Theory and Practice. Second

1115 Edition. Oxford, United Kingdom: Blackwell Publishing. 456 p.

1116 Skalski, J.R., Hoffmann, A., Ransom, B.H. and Steig, T.W. 1993. Fixed-location

1117 hydroacoustic monitoring designs for estimating fish passage using stratified random

1118 and systematic sampling. Can. J. Fish. Aquat. Sci. 50: 1208-1221. doi:10.1139/f93-

1119137.

1120 Snorrason, S.S., Jónasson, P.M., Jonsson, B., Lindem, T., Malmquist, H.J., Sandlund, O.T.

1121 and Skúlason, S. 1992. Population dynamics of the planktivorous arctic charr

1122 Salvelinus alpinus ("murtá") in Thingvallavatn. Oikos 64: 352 - 364.

1123 doi:10.2307/3545057.

1124 Spigarelli, S.A., Goldstein, R.M., Prepejchal, W. and Thommes, M.M. 1982. Fish

1125 abundance and distribution near three heated effluents to Lake Michigan. Can. J. Fish.

1126 Aquat. Sci. 39: 305-315. doi:10.1139/f82-042.

1127 Spigarelli, S.A., Romberg, G.P. and Thorne, R.E. 1973. A technique for simultaneous, echo 1128 location of fish and thermal plume mapping. Trans. Am. Fish. Soc. 102: 462-466. 
1130 Stanton, T.K., Chu, D., Jech, J.M. and Irish, J.D. 2010. New broadband methods for 1131 resonance classification and high-resolution imagery of fish with swimbladders using 1132 a modified commercial broadband echosounder. ICES J. Mar. Sci. 67: 365-378. 1133 doi:10.1093/icesjms/fsp262.

1134 Steig, T. and Johnston, S. V 1996. Monitoring fish movement patterns in a reservoir using 1135 horizontally scanning split-beam techniques. ICES J. Mar. Sci. 53: 435-441. 1136 doi:10.1006/jmsc.1996.0061.

1137 Stockwell, J.D., Yule, D.L., Gorman, O.T., Isaac, E.J. and Moore, S.A. 2006. Evaluation of 1138 bottom trawls as compared to acoustics to assess adult Lake Herring (Coregonus 1139 artedi) abundance in Lake Superior. J. Great Lakes Res. 32: 280-292. 1140 doi:10.3394/0380-1330(2006)32[280:EOBTAC]2.0.CO;2.

1141 Stockwell, J.D., Yule, D.L., Hrabik, T.R., Adams, J. V., Gorman, O.T. and Holbrook, B. V. 1142 2007. Vertical distribution of fish biomass in Lake Superior: Implications for day 1143 bottom trawl surveys. North Am. J. Fish. Manag. 27: 735-749. doi:10.1577/M06$1144 \quad 116.1$.

1145 Sund, O. 1935. Echo sounding in fishery research. Nature 135: 953. doi:

$1146 \quad 10.1038 / 135953 \mathrm{a} 0$.

1147 Swierzowski, A. 2001. Diel variations in the vertical distribution and density of vendace 1148 Coregonus albula (L.) in Pluszne Lake. Arch. Polish Fish. 9: 147-156. 
doi:10.1007/BF00397858.

1150 Świerzowski, A. and Doroszczyk, L. 2004. Seasonal differences in situ measurements of 1151 the target strength of vendace (Coregonus albula L.) in lake Pluszne. Hydroacoustics 1152 7: $217-226$.

1153 Swierzowski, A. and Godlewska, A. 2001. The effect of the seasonal changes of 1154 environment on the hydroacoustically monitored spatial distribution and density of 1155 vendace (Coregonus albula L.) in Pluszne Lake. Hydroacoustics 4: 231-236.

1156 Sydanoja, A., Helminen, H. and Sarvala, J. 1995. Vertical migrations of vendace 1157 (Coregonus albula) in a thermally unstratified lake (Pyhajarvi, SW Finland). Arch. fur $1158 \quad$ Hydrobiol. 46: 277-286.

1159 Taabu-Munyaho, A., Kayanda, R.J., Everson, I., Grabowski, T.B. and Marteinsdóttir, G. 1160 2013. Distribution and exploitation of Nile perch Lates niloticus in relation to 1161 stratification in Lake Victoria, East Africa. J. Great Lakes Res. 39: 466-475. 1162 doi:10.1016/j.jglr.2013.06.009.

1163 Taabu-Munyaho, A., Nyamweya, C.S., Sitoki, L., Kayanda, R., Everson, I. and 1164 Marteinsdóttir, G. 2014. Spatial and temporal variation in the distribution and density 1165 of pelagic fish species in Lake Victoria, East Africa. Aquat. Ecosyst. Health Manag. 1166 17: 52-61. doi:10.1080/14634988.2014.876886.

1167 Tan, X., Kang, M., Tao, J., Li, X. and Huang, D. 2011. Hydroacoustic survey of fish 1168 density, spatial distribution, and behavior upstream and downstream of the Changzhou 
1169 Dam on the Pearl River, China. Fish. Sci. 77: 891-901. doi:10.1007/s12562-011$1170 \quad 0400-5$

1171 Tao, J., Gao, Y., Qiao, Y., Zheng, H., Wang, X., Wan, L. and Chang, J. 2010.

1172 Hydroacoustic observation of fish spatial patterns and behavior in the ship lock and

1173 adjacent areas of Gezhouba Dam, Yangtze River. Acta Ecol. Sin. 30: 233-239.

1174 doi:10.1016/j.chnaes.2010.06.008.

1175 TeWinkel, L.M. and Fleischer, G.W. 1999. Vertical migration and nighttime distribution of

1176 adult bloaters in Lake Michigan. Trans. Am. Fish. Soc. 128: 459-474.

1177 doi:10.1577/1548-8659(1999)128<0459:VMANDO>2.0.CO;2.

1178 Thorne, R.E. 1979. Hydroacoustic estimates of adult sockeye salmon (Oncorhynchus

1179 nerka) in Lake Washington, 1972-75. Journal of the Fish. Res. Board of Canada 36:

$1180 \quad$ 1145-1149. doi:10.1139/f79-161.

1181 Thorne, R.E. 1983. Assessment of population abundance by hydroacoustics. Biol.

1182 Oceanogr. 2: 253-262. doi:10.1080/01965581.1983.10749461.

1183 Thorne, R.E. and Dawson, J.J. 1974. An acoustic estimate of the escapement of sockeye 1184 salmon (Oncorhynchus nerka) into Lake Washington in 1971. J. Fish. Res. Board 1185 Canada 31: 222-225. doi:10.1139/f74-038.

1186 Trenkel, V.M., Ressler, P.H., Jech, M., Giannoulaki, M. and Taylor, C. 2011. Underwater 1187 acoustics for ecosystem-based management: state of the science and proposals for 1188 ecosystem indicators. Mar. Ecol. Prog. Ser. 442: 285-301. doi:10.3354/meps09425. 
1189 Trevorrow, M. V. 1996. Multifrequency acoustic investigations of juvenile and adult fish in 1190 Lake Biwa, Japan. J. Acoust. Soc. Am. 100: 3042-3052. doi:10.1121/1.417116.

1191 Trevorrow, M. V. 1998. Boundary scattering limitations to fish detection in shallow waters. 1192 Fish. Res. 35: 127-135. doi:10.1016/S0165-7836(98)00067-8.

1193 Tumwebaze, R., Cowx, I., Ridgway, S., Getabu, A. and MacLennan, D.N. 2007. Spatial 1194 and temporal changes in the distribution of Rastrineobola argentea in Lake Victoria. 1195 Aquat. Ecosyst. Health Manag. 10: 398-406. doi:10.1080/14634980701709527.

1196 Tušer, M., Frouzová, J., Balk, H., Muška, M., Mrkvička, T. and Kubečka, J. 2014.

1197 Evaluation of potential bias in observing fish with a DIDSON acoustic camera. Fish.

1198 Res. 155: 114-121. doi:10.1016/j.fishres.2014.02.031.

1199 Tušer, M., Kubečka, J., Frouzová, J. and Jarolím, O. 2009. Fish orientation along the 1200 longitudinal profile of the Římov reservoir during daytime: Consequences for 1201 horizontal acoustic surveys. Fish. Res. 96: 23-29. doi:10.1016/j.fishres.2008.09.022.

1202 Vašek, M., Kubečka, J., Peterka, J., Čech, M., Draštík, V., Hladík, M., Prchalová, M. and 1203 Frouzová, J. 2004. Longitudinal and vertical spatial gradients in the distribution of fish 1204 within a canyon-shaped reservoir. Int. Rev. Hydrobiol. 89: 352-362. 1205 doi:10.1002/iroh.200410734.

1206 Vigliano, P.H., Beauchamp, D.A., Milano, D., Macchi, P.J., Alonso, M.F., Asorey, M.I.G., 1207 Denegri, M.A., Ciancio, J.E., Lippolt, G., Rechencq, M. and Barriga, J.P. 2009. 1208 Quantifying predation on galaxiids and other native organisms by introduced Rainbow 
1209 Trout in an ultraoligotrophic Lake in Northern Patagonia, Argentina: A bioenergetics 1210 modeling approach. Trans. Am. Fish. Soc. 138: 1405-1419. doi:10.1577/T08-067.1.

1211 Vigliano, P.H., Macchi, P.J., Alonso, M., Denegri, M.A., Asorey, M.G. and Lippolt, G.

1212 2008. Gill net and hydroacoustic fish resource evaluation of an ultraoligotrophic lake

1213 of Northern Patagonia, Argentina. Trans. Am. Fish. Soc. 49: 587-609.

1214 Vondracek, B. and Degan, D.J. 1995. Among- and within-transect variability in estimates 1215 of Shad abundance made with hydroacoustics. North Am. J. Fish. Manag. 15: 9331216 939. doi:10.1577/1548-8675(1995)015<0933:AAWVIE>2.3.CO;2.

1217 Walline, P.D., Pisanty, S. and Lindem, T. 1992. Acoustic assessment of the number of 1218 pelagic fish in Lake Kinneret, Israel. HydroBiologia (Bratisl). 231: 153-163. 1219 doi:10.1007/BF00018199.

1220 Wang, K., Duan, X.B., Liu, S.P., Chen, D.Q. and Liu, M.D. 2013. Acoustic assessment of 1221 the fish spatio-temporal distribution during the initial filling of the Three Gorges 1222 Reservoir, Yangtze River (China), from 2006 to 2010. J. Appl. Ichthyol. 29: 13951223 1401. doi:10.1111/jai.12370.

1224 Wanzenbock, J., Mehner, T., Schulz, M., Gassner, H. and Winfield, I.J. 2003. Quality 1225 assurance of hydroacoustic surveys: the repeatability of fish-abundance and biomass 1226 estimates in lakes within and between hydroacoustic systems. ICES J. Mar. Sci. 60: 1227 486-492. doi:10.1016/S1054-3139(03)00030-4.

1228 Warner, D.M., Rudstam, L.G. and Klumb, R.A. 2002. In situ target strength of alewives in 
Wheeland, L.J. and Rose, G.A. 2014. Quantifying fish avoidance of small acoustic survey vessels in boreal lakes and reservoirs. Ecol. Freshw. Fish 24: 67-76.

Wheeland, L.J. and Rose, G.A. 2016. Acoustic measures of lake community size spectra. doi:10.1111/eff.12126.

Winemiller, K.O. and Jepsen, D.B. 1998. Effects of seasonality and fish movement on Can. J. Fish. Aquat. Sci. 73: 557-564. doi:10.1139/cjfas-2014-0446.

\section{9} tropical river food webs. J. Fish Biol. 53: 267-296. doi:10.1111/j.10958649.1998.tb01032.x.

Winfield, I.J., Bean, C.W. and Hewitt, D.P. 2002. The relationship between spatial distribution and diet of Arctic Charr, Salvelinus alpinus, in Loch Ness, U.K. Environ. Biol. Fishes 64: 63-73. doi:10.1023/A:1016009408315.

Winfield, I.J., Fletcher, J.M., James, J. Ben and Bean, C.W. 2009. Assessment of fish populations in still waters using hydroacoustics and survey gill netting: Experiences with Arctic charr (Salvelinus alpinus) in the UK. Fish. Res. 96: 30-38. doi:10.1016/j.fishres.2008.09.013.

1246 Winfield, I.J., Fletcher, J.M. and James, J.B. 2007. Seasonal variability in the abundance of 1247 Arctic charr (Salvelinus alpinus (L.)) recorded using hydroacoustics in Windermere, $1248 \quad$ UK and its implications for survey design. Ecol. Freshw. Fish 16: 64-69. 
doi:10.1111/j.1600-0633.2006.00170.x.

1250 Winfield, I.J., van Rijn, J. and Valley, R.D. 2015. Hydroacoustic quantification and assessment of spawning grounds of a lake salmonid in a eutrophicated water body. Ecol. Inform. 30: 235-240. doi:10.1016/j.ecoinf.2015.05.009.

1253 Wojtal-Frankiewicz, A., Frankiewicz, P., Jurczak, T., Grennan, J. and McCarthy, T.K. 1254 2009. Comparison of fish and phantom midge influence on cladocerans diel vertical 1255 migration in a dual basin lake. Aquat. Ecol. 44: 243-254. doi:10.1007/s10452-009$1256 \quad 9280-5$

1257 Woolnough, D.A., Downing, J.A. and Newton, T.J. 2009. Fish movement and habitat use 1258 depends on water body size and shape. Ecol. Freshw. Fish 18: 83-91. 10.1111/j.1600$1259 \quad 0633.2008 .00326 . x$.

1260 Ye, S., Lian, Y., Godlewska, M., Liu, J. and Li, Z. 2013. Day-night differences in 1261 hydroacoustic estimates of fish abundance and distribution in Lake Laojianghe, China. 1262 J. Appl. Ichthyol. 29: 1423-1429. doi:10.1111/jai.12367.

1263 Yule, D.L., Adams, J. V., Stockwell, J.D. and Gorman, O.T. 2007. Using multiple gears to 1264 assess acoustic detectability and biomass of fish species in Lake Superior. North Am. 1265 J. Fish. Manag. 27: 106-126. doi:10.1577/M06-090.1.

1266 Yule, D.L., Stockwell, J.D., Schreiner, D.R., Evrard, L.M., Balge, M. and Hrabik, T.R. 1267 2008. Can pelagic forage fish and spawning cisco (Coregonus artedi) biomass in the 1268 western arm of Lake Superior be assessed with a single summer survey? Fish. Res. 96: 
1269 39-50. doi:10.1016/j.fishres.2008.09.012.

1270 Zhang, H., Wei, Q.W., Du, H., Shen, L., Li, Y.H. and Zhao, Y. 2009. Is there evidence that 1271 the Chinese paddlefish (Psephurus gladius) still survives in the upper Yangtze River?

1272 Concerns inferred from hydroacoustic and capture surveys, 2006-2008. J. Appl.

1273 Ichthyol. 25: 95-99. doi:10.1111/j.1439-0426.2009.01268.x.

1274 Zhang, H., Wei, Q.W., Kyanrd, B.E., Du, H., Yang, D.G. and Chen, X.H. 2011. Spatial 1275 structure and bottom characteristics of the only remaining spawning area of Chinese

1276 sturgeon in the Yangtze River. J. Appl. Ichthyol. 27: 251-256. doi:10.1111/j.1439$1277 \quad$ 0426.2011.01708.x. 


\section{Tables}

Table 1. A summary of fish length-target strength relationships that have been quantified in freshwater. The equation is

$T S=a \log (T L)+b$, where $T S=$ target strength in decibels, $T L=$ fish total length $(\mathrm{cm})$, and $a$ and $b$ are constants.

\begin{tabular}{|c|c|c|c|c|c|c|c|}
\hline Species & Family & $\begin{array}{l}\text { Acoustic } \\
\text { Frequency } \\
(\mathbf{k H z})\end{array}$ & Aspect & $a$ & $b$ & Region & Reference \\
\hline $\begin{array}{l}\text { Alosa } \\
\text { pseudoharengus }\end{array}$ & Clupeidae & 70 & dorsal & 20.53 & -64.25 & $\begin{array}{l}\text { Laurentian Great Lakes, } \\
\text { NE United States }\end{array}$ & Warner et al. 2002 \\
\hline $\begin{array}{l}\text { Alosa } \\
\text { pseudoharengus, } \\
\text { Osmerus } \\
\text { mordax, } \\
\text { Gasterosteus } \\
\text { aculeatus, } \\
\text { Pungitius } \\
\text { pungitius }\end{array}$ & $\begin{array}{l}\text { Clupeidae, } \\
\text { Osmeridae, } \\
\text { Gasterosteidae }\end{array}$ & 120 & dorsal & 52.60 & -100.00 & Laurentian Great Lakes & $\begin{array}{l}\text { Fleischer et al. } \\
\text { 1997* }\end{array}$ \\
\hline $\begin{array}{l}\text { Coregonus } \\
\text { albula }\end{array}$ & Salmonidae & 120 & dorsal & 25.50 & -70.90 & Germany & Mehner 2006b \\
\hline $\begin{array}{l}\text { Coregonus } \\
\text { albula }\end{array}$ & Salmonidae & 120 & dorsal & 20.00 & -65.40 & Poland & $\begin{array}{l}\text { Swierzowski and } \\
\text { Doroszczyk } 2004\end{array}$ \\
\hline Coregonus hoyi & Salmonidae & 120 & dorsal & 52.60 & -107.00 & Laurentian Great Lakes & $\begin{array}{l}\text { Fleischer et al. } \\
1997^{*}\end{array}$ \\
\hline
\end{tabular}




\begin{tabular}{|c|c|c|c|c|c|c|c|}
\hline Species & Family & $\begin{array}{l}\text { Acoustic } \\
\text { Frequency } \\
(\mathbf{k H z})\end{array}$ & Aspect & $a$ & $b$ & Region & Reference \\
\hline $\begin{array}{l}\text { Coregonus } \\
\text { lavaretus }\end{array}$ & Salmonidae & 200 & $\begin{array}{l}\text { side (full side vs } \\
\text { head/tail) }\end{array}$ & 39.70 & -90.00 & Finland & Lilja et al. $2000^{* *}$ \\
\hline Cyprinus carpio & Cyprinidae & 120 & $\begin{array}{l}\text { side (full side vs } \\
\text { head/tail) }\end{array}$ & 23.97 & -103.90 & Czech republic & $\begin{array}{l}\text { Frouzova et al. } \\
2005\end{array}$ \\
\hline Esox lucius & Esocidae & 200 & $\begin{array}{l}\text { side (full side vs } \\
\text { head/tail) }\end{array}$ & 28.60 & -74.00 & Finland & Lilja et al. $2000^{* *}$ \\
\hline Lates niloticus & Latidae & 70 & side $\left(-90^{\circ}\right.$ to $+90^{\circ}$ & 32.11 & -86.79 & East Africa & Kayanda et al. 2012 \\
\hline Lates niloticus & Latidae & 120 & side $\left(-90^{\circ}\right.$ to $+90^{\circ}$ & 30.15 & -84.14 & East Africa & Kayanda et al. 2012 \\
\hline $\begin{array}{l}\text { Morone } \\
\text { americana }\end{array}$ & Moronidae & 120 & dorsal & 26.48 & -69.45 & NE United States & $\begin{array}{l}\text { Hartman and Nagy } \\
2005\end{array}$ \\
\hline $\begin{array}{l}\text { Morone } \\
\text { saxatalis }\end{array}$ & Moronidae & 120 & dorsal & 15.37 & -56.26 & NE United States & $\begin{array}{l}\text { Hartman and Nagy } \\
2005\end{array}$ \\
\hline Osmerus mordax & Osmeridae & 70,120 & dorsal & 19.90 & -67.80 & Laurentian Great Lakes & Rudstam et al. 2003 \\
\hline Perca fluviatilis & Percidae & 120 & $\begin{array}{l}\text { side (full side vs } \\
\text { head/tail) }\end{array}$ & 20.96 & -97.05 & Czech republic & $\begin{array}{l}\text { Frouzova et al. } \\
2005\end{array}$ \\
\hline Rutilus rutilus & Cyprinidae & 70 & dorsal & 18.40 & -69.30 & France & $\begin{array}{l}\text { Guillard and } \\
\text { Gerdeaux } 1993\end{array}$ \\
\hline
\end{tabular}




\begin{tabular}{|c|c|c|c|c|c|c|c|}
\hline Species & Family & $\begin{array}{l}\text { Acoustic } \\
\text { Frequency } \\
(\mathbf{k H z})\end{array}$ & Aspect & $a$ & $b$ & Region & Reference \\
\hline Rutilus rutilus & Cyprinidae & 120 & $\begin{array}{l}\text { side (full side vs } \\
\text { head/tail) }\end{array}$ & 17.02 & -87.37 & Czech republic & $\begin{array}{l}\text { Frouzova et al. } \\
2005\end{array}$ \\
\hline Salmo salar & Salmonidae & 200 & $\begin{array}{l}\text { side (full side vs } \\
\text { head/tail) }\end{array}$ & 25.60 & -73.00 & Finland & Lilja et al. $2000 * *$ \\
\hline Salmo trutta & Salmonidae & 120 & $\begin{array}{l}\text { side (full side vs } \\
\text { head/tail) }\end{array}$ & 10.96 & -76.79 & Czech republic & $\begin{array}{l}\text { Frouzova et al. } \\
2005\end{array}$ \\
\hline Salmo trutta & Salmonidae & 200 & $\begin{array}{l}\text { side (full side vs } \\
\text { head/tail) }\end{array}$ & 28.90 & -78.00 & Finland & Lilja et al. $2000 * *$ \\
\hline Salmo trutta & Salmonidae & 420 & $\begin{array}{l}\text { side (full side vs } \\
\text { head/tail aspect vs } \\
\text { mean all-aspect - } \\
360^{\circ} \text { ) }\end{array}$ & 34.20 & -114.00 & UK & $\begin{array}{l}\text { Kubecka and } \\
\text { Duncan 1998a }\end{array}$ \\
\hline Rutilus rutilus & Cyprinidae & 420 & $\begin{array}{l}\text { side (full side vs } \\
\text { head/tail aspect vs } \\
\text { mean all-aspect - } \\
360^{\circ} \text { ) }\end{array}$ & 29.30 & -96.70 & UK & $\begin{array}{l}\text { Kubecka and } \\
\text { Duncan 1998a }\end{array}$ \\
\hline Rutilus rutilus & Cyprinidae & 200 & $\begin{array}{l}\text { side (full side vs } \\
\text { head/tail aspect vs } \\
\text { mean all-aspect - } \\
360^{\circ} \text { ) }\end{array}$ & 15.80 & -78.00 & UK & $\begin{array}{l}\text { Kubecka and } \\
\text { Duncan 1998a }\end{array}$ \\
\hline
\end{tabular}




\begin{tabular}{|c|c|c|c|c|c|c|c|}
\hline Species & Family & $\begin{array}{l}\text { Acoustic } \\
\text { Frequency } \\
(\mathbf{k H z})\end{array}$ & Aspect & $a$ & $b$ & Region & Reference \\
\hline $\begin{array}{l}\text { Carassius } \\
\text { carassius, } \\
\text { Cyprinus carpio }\end{array}$ & Cyprinidae & 420 & $\begin{array}{l}\text { side (full side vs } \\
\text { head/tail aspect vs } \\
\text { mean all-aspect - } \\
360^{\circ} \text { ) }\end{array}$ & 19.60 & -76.20 & UK & $\begin{array}{l}\text { Kubecka and } \\
\text { Duncan 1998a }\end{array}$ \\
\hline $\begin{array}{l}\text { Carassius } \\
\text { carassius, } \\
\text { Cyprinus carpio }\end{array}$ & Cyprinidae & 200 & $\begin{array}{l}\text { side (full side vs } \\
\text { head/tail aspect vs } \\
\text { mean all-aspect - } \\
360^{\circ} \text { ) }\end{array}$ & 22.60 & -89.80 & UK & $\begin{array}{l}\text { Kubecka and } \\
\text { Duncan 1998a }\end{array}$ \\
\hline $\begin{array}{l}\text { Leuciscus } \\
\text { leuciscus, } \\
\text { Leuciscus } \\
\text { cephalus }\end{array}$ & Cyprinidae & 420 & $\begin{array}{l}\text { side (full side vs } \\
\text { head/tail aspect vs } \\
\text { mean all-aspect - } \\
360^{\circ} \text { ) }\end{array}$ & 27.30 & -93.50 & UK & $\begin{array}{l}\text { Kubecka and } \\
\text { Duncan 1998a }\end{array}$ \\
\hline $\begin{array}{l}\text { Leuciscus } \\
\text { leuciscus, } \\
\text { Leuciscus } \\
\text { cephalus }\end{array}$ & Cyprinidae & 200 & $\begin{array}{l}\text { side (full side vs } \\
\text { head/tail aspect vs } \\
\text { mean all-aspect - } \\
360^{\circ} \text { ) }\end{array}$ & 17.90 & -82.10 & UK & $\begin{array}{l}\text { Kubecka and } \\
\text { Duncan 1998a }\end{array}$ \\
\hline Perca fluviatilis & Percidae & 420 & $\begin{array}{l}\text { side (full side vs } \\
\text { head/tail aspect vs } \\
\text { mean all-aspect - } \\
360^{\circ} \text { ) }\end{array}$ & 30.30 & -98.90 & UK & $\begin{array}{l}\text { Kubecka and } \\
\text { Duncan 1998a }\end{array}$ \\
\hline Perca fluviatilis & Percidae & 200 & $\begin{array}{l}\text { side (full side vs } \\
\text { head/tail aspect vs } \\
\text { mean all-aspect - } \\
360^{\circ} \text { ) }\end{array}$ & 18.20 & -83.00 & UK & $\begin{array}{l}\text { Kubecka and } \\
\text { Duncan 1998a }\end{array}$ \\
\hline
\end{tabular}




\begin{tabular}{|c|c|c|c|c|c|c|c|}
\hline Species & Family & $\begin{array}{l}\text { Acoustic } \\
\text { Frequency } \\
(\mathbf{k H z})\end{array}$ & Aspect & $a$ & $b$ & Region & Reference \\
\hline Abramis brama & Cyprinidae & 420 & $\begin{array}{l}\text { side (full side vs } \\
\text { head/tail aspect vs } \\
\text { mean all-aspect - } \\
360^{\circ} \text { ) }\end{array}$ & 31.40 & -102.10 & UK & $\begin{array}{l}\text { Kubecka and } \\
\text { Duncan 1998a }\end{array}$ \\
\hline Abramis brama & Cyprinidae & 200 & $\begin{array}{l}\text { side (full side vs } \\
\text { head/tail aspect vs } \\
\text { mean all-aspect - } \\
360^{\circ} \text { ) }\end{array}$ & 18.20 & -81.60 & UK & $\begin{array}{l}\text { Kubecka and } \\
\text { Duncan 1998a }\end{array}$ \\
\hline $\begin{array}{l}\text { Onchorhynchus } \\
\text { mykiss }\end{array}$ & Salmonidae & 420 & $\begin{array}{l}\text { side (full side vs } \\
\text { head/tail aspect vs } \\
\text { mean all-aspect - } \\
360^{\circ} \text { ) }\end{array}$ & 26.90 & -96.00 & UK & $\begin{array}{l}\text { Kubecka and } \\
\text { Duncan 1998a }\end{array}$ \\
\hline $\begin{array}{l}\text { Onchorhynchus } \\
\text { mykiss }\end{array}$ & Salmonidae & 200 & $\begin{array}{l}\text { side (full side vs } \\
\text { head/tail aspect vs } \\
\text { mean all-aspect - } \\
360^{\circ} \text { ) }\end{array}$ & 18.60 & -87.20 & UK & $\begin{array}{l}\text { Kubecka and } \\
\text { Duncan 1998a }\end{array}$ \\
\hline
\end{tabular}

* Parameters converted from those published to correspond with $\mathrm{TS}_{\mathrm{dB}}=\mathrm{aLog}_{10}\left(\right.$ length $\left._{\mathrm{cm}}\right)$ - $\mathrm{b}$ for comparison.

**Side aspect TS, with mean estimated in the logarithmic domain; approximately $1 \mathrm{~dB}$ lower than in the more appropriate arithmetic domain (MacLennan and Simmonds 1992). 


\section{Figure Captions}

Figure 1. Echogram from Cold Spring Pond, Newfoundland, showing salmonid targets at $200 \mathrm{kHz}$ in July 2010. The echogram spans approximately $1 \mathrm{~km}$ with lakebed depths ranging around $30 \mathrm{~m}$ and surface temperatures $18.8^{\circ} \mathrm{C}$.

Figure 2. Count of published hydroacoustic studies performed in each country. Many studies occurred across national boundaries and so are counted more than once. Inset: Map of the locations of hydroacoustic studies included in this review. Map created using Esri Data and Maps (Esri 2016: Redlands, California. Available at http://www.arcgis.com/home/item.html?id=170b5e6529064b8d9275168687880359 ) .

Figure 3. Number of water bodies included in the freshwater hydroacoustics publications reviewed in the present study. Inset: Percentage of studies with different counts of water bodies researched. Very few studies reviewed here involved more than 4 bodies of water.

Figure 4. Histogram displaying the count of hydroacoustic studies assessed here that focused on or heavily involved each fish family. Inset: Comparison of counts of studies reviewed here that involve each fish family.

Figure 5. Histogram displaying the count of hydroacoustic studies assessed here that focused on or heavily involved each fish species.

Figure 6. Some TS-length models for a) Coregonids (dorsal aspect), b) Salmo trutta (side aspect), c) Clupeids (dorsal aspect), and d) Cyprinids (dorsal aspect). Colours indicate authors: black (Kubecka and Duncan 1998); red (Fleischer et al. 1997); blue (Mehner 2006b); brown (Swierzowski and Doroszczyk 2004); green (Frouzova et al. 2005); orange (Lilja et al. 2000); purple (Warner et al. 2002). Line styles indicate acoustic frequency: $70 \mathrm{kHz}$ (dash dot); $120 \mathrm{kHz}$ (solid); $200 \mathrm{kHz}$ (small dash); $420 \mathrm{kHz}$ (large dash). For panel b) open arrowhead indicates $S$. salar, closed arrowhead O. mykiss; panel d) open arrowhead indicates Carassius carassius, filled arrowhead Leuciscus spp, double arrowhead Abramis brama, no arrowhead Rutilus rutilus.

Figure 7. Histogram displaying the duration of studies reviewed in years. Inset: The proportion of studies in this review for each period of duration (1 year or less, $>1-2$ years, $>2-3$ years, $>3-4$ years, $>5-6$ years, $>6$ years; note that proportions do not sum to $100 \%$ as a result of rounding). 


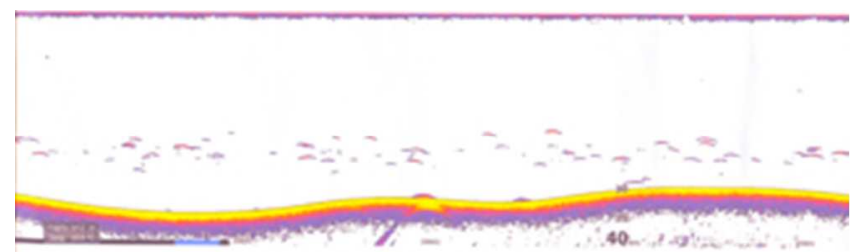

Echogram from Cold Spring Pond, Newfoundland, showing salmonid targets at $200 \mathrm{kHz}$ in July 2010. The echogram spans approximately $1 \mathrm{~km}$ with lakebed depths ranging around $30 \mathrm{~m}$ and surface temperatures $18.8^{\circ} \mathrm{C}$

$112 \times 34 \mathrm{~mm}(72 \times 72 \mathrm{DPI})$ 


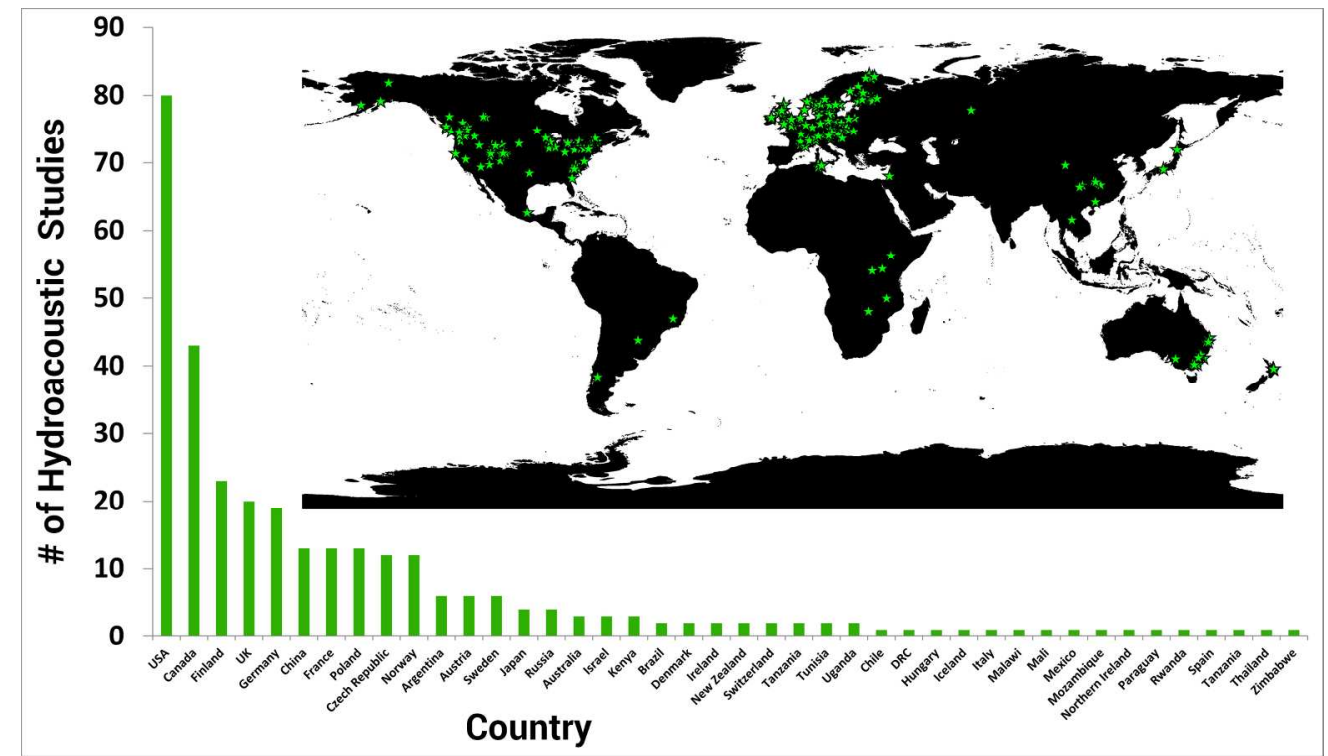

Count of published hydroacoustic studies performed in each country. Many studies occurred across national boundaries and so are counted more than once. Inset: Map of the locations of hydroacoustic studies included in this review.

$205 \times 118 \mathrm{~mm}(300 \times 300 \mathrm{DPI})$ 


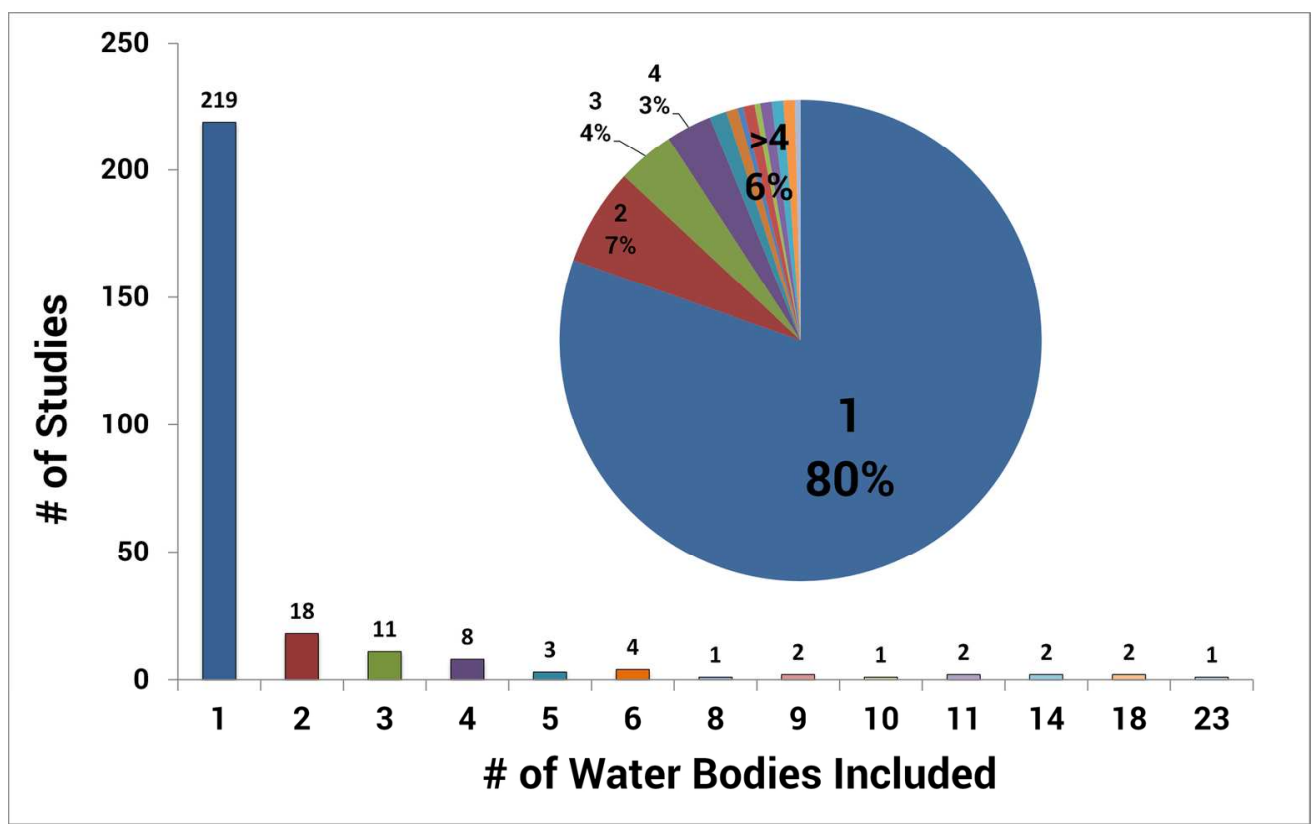

Number of water bodies included in the freshwater hydroacoustics publications reviewed in the present study. Inset: Percentage of studies with different counts of water bodies researched. Very few studies reviewed here involved more than 4 bodies of water. $161 \times 101 \mathrm{~mm}$ (300 x 300 DPI) 


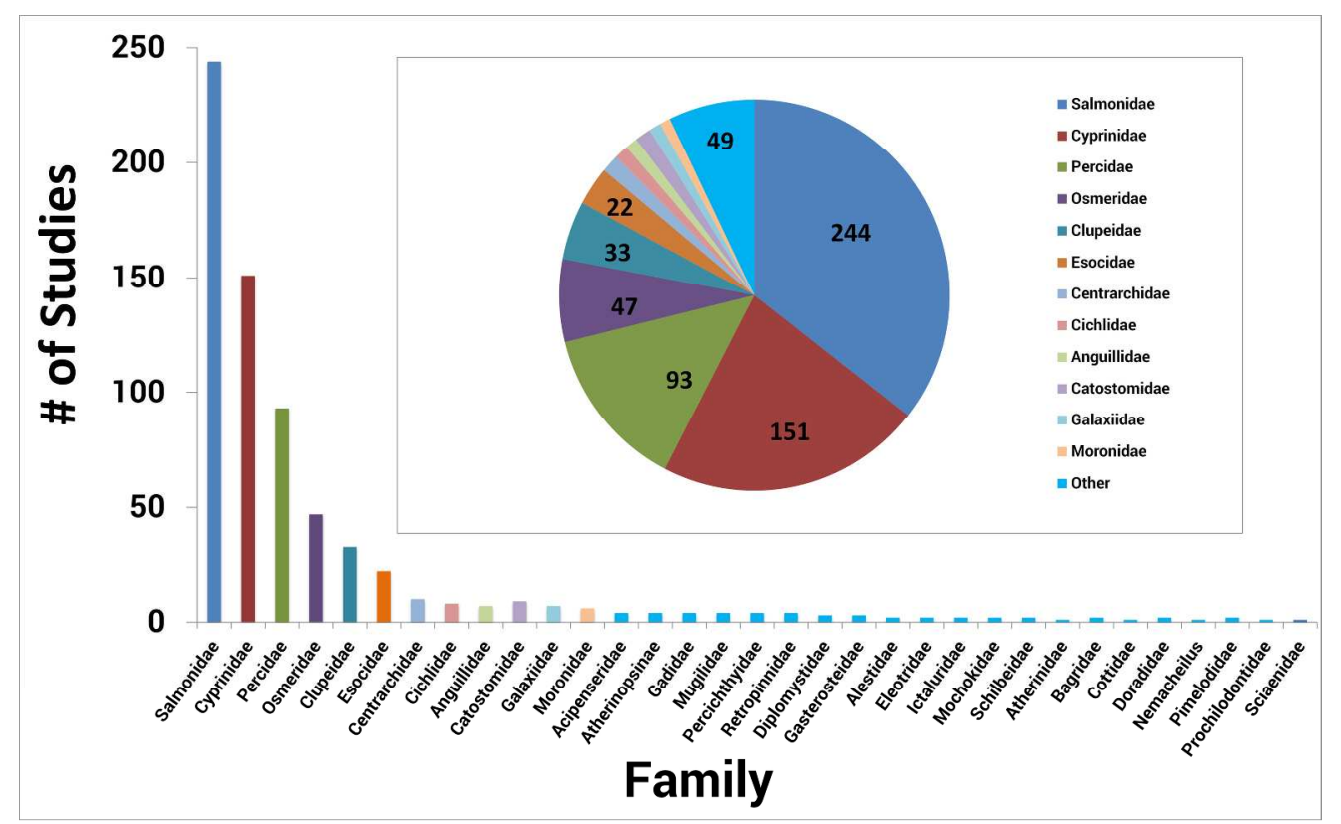

Histogram displaying the count of hydroacoustic studies assessed here that focused on or heavily involved each fish family. Inset: Comparison of counts of studies reviewed here that involve each fish family. $251 \times 155 \mathrm{~mm}(300 \times 300$ DPI) 


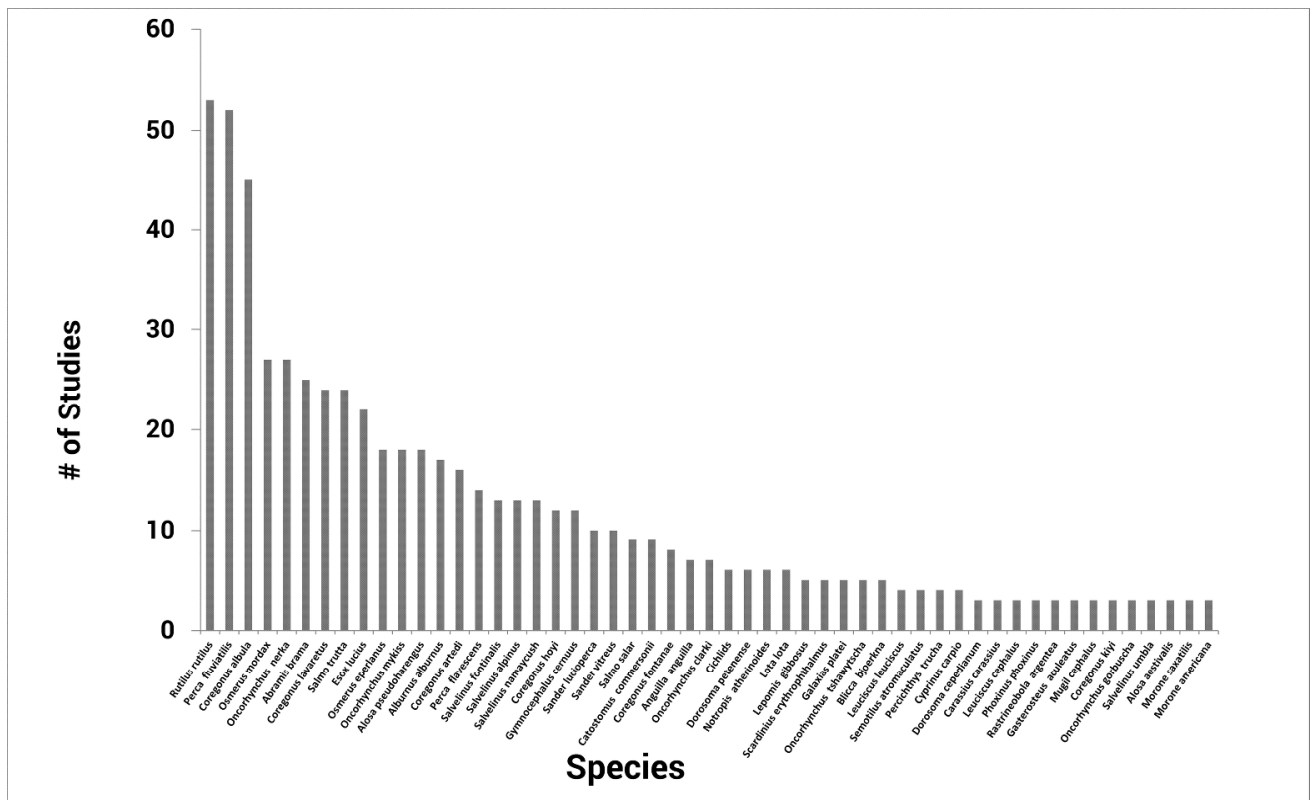

Histogram displaying the count of hydroacoustic studies assessed here that focused on or heavily involved each fish species.

$266 \times 163 \mathrm{~mm}(300 \times 300$ DPI) 

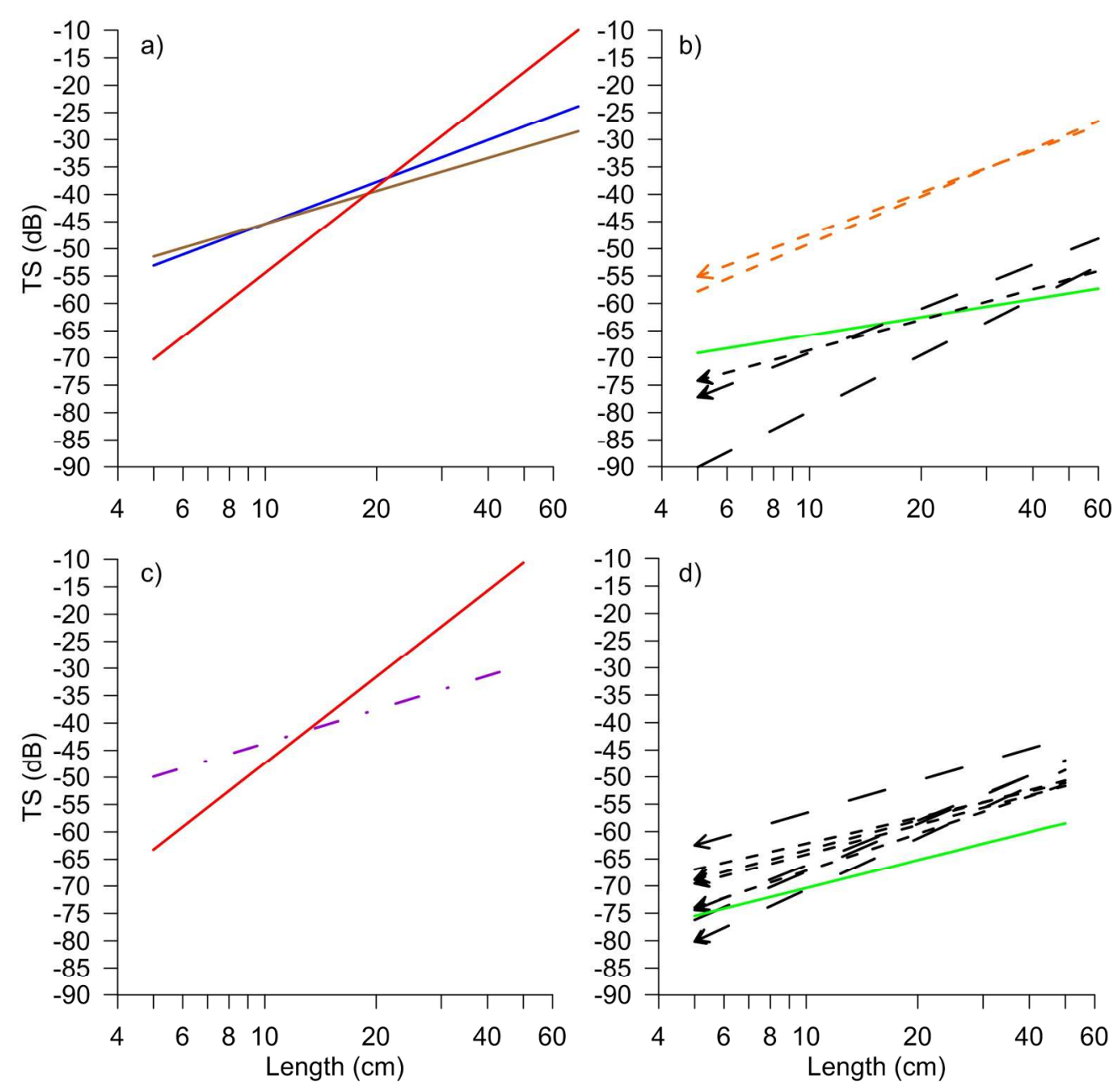

Some TS-length models for a) Coregonids (dorsal aspect), b) Salmo trutta (side aspect), c) Clupeids (dorsal aspect), and d) Cyprinids (dorsal aspect). Colours indicate authors: black (Kubecka and Duncan 1998); red (Fleischer et al. 1997); blue (Mehner 2006b); brown (Swierzowski and Doroszczyk 2004); green (Frouzova et al. 2005); orange (Lilja et al. 2000); purple (Warner et al. 2002). Line styles indicate acoustic frequency:

$70 \mathrm{kHz}$ (dash dot); $120 \mathrm{kHz}$ (solid); $200 \mathrm{kHz}$ (small dash); $420 \mathrm{kHz}$ (large dash). For panel b) open arrowhead indicates S. salar, closed arrowhead O. mykiss; panel d) open arrowhead indicates Carassius carassius, filled arrowhead Leuciscus spp, double arrowhead Abramis brama, no arrowhead Rutilus rutilus. $202 \times 196 \mathrm{~mm}$ (300 x 300 DPI) 


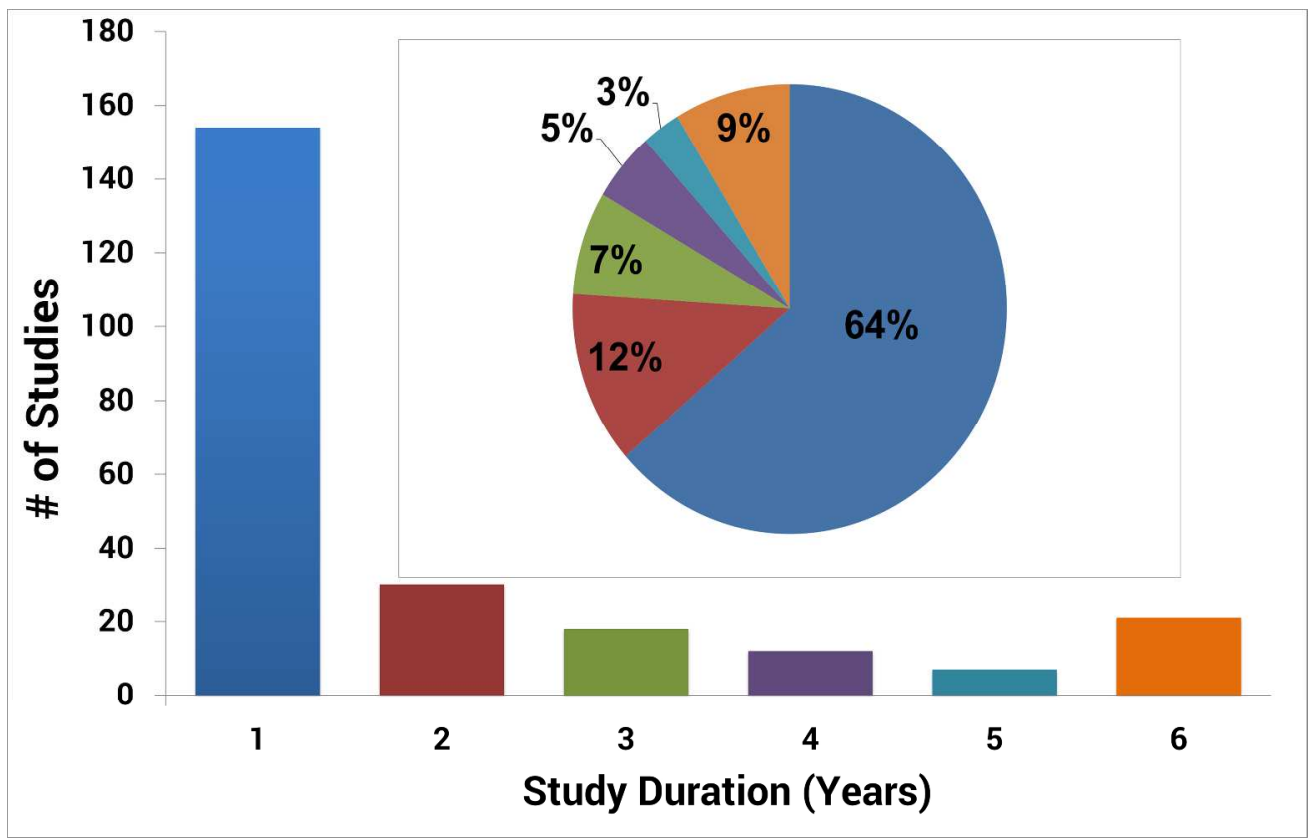

Histogram displaying the duration of studies reviewed in years. Inset: The proportion of studies in this review for each period of duration (1 year or less, $>1-2$ years, $>2-3$ years, $>3-4$ years, $>5-6$ years, $>6$ years; note that proportions do not sum to $100 \%$ as a result of rounding).

$262 \times 167 \mathrm{~mm}(300 \times 300 \mathrm{DPI})$ 